\title{
The Determinants of Liquidity in the Corporate Bond Markets: An Application of Latent Liquidity ${ }^{1}$
}

\author{
George Chacko \\ Sriketan Mahanti \\ Harvard Business School State Street Global Markets \\ Gaurav Mallik \\ State Street Global Markets \\ Marti Subrahmanyam \\ Stern School of Business, New York University
}

December 8, 2005

\begin{abstract}
${ }^{1}$ We would like to thank Peter Hecht and Jeffrey Sutthoff for their unstinting help and advice in putting together the databases for this paper. We also thank Craig Emrick, Amrut Nashikkar, Lasse Pedersen,and Caroline Shi for helpful comments on a previous version of the paper. George Chacko (gchacko@hbs.edu) is at Harvard Business School, Boston, MA 02163, +1 617495 6884; Gaurav Mallik (gmallik@statestreet.com) and Sriketan Mahanti (smahanti@statestreet.com) are at State Street Global Markets, 1 Lincoln Street, 5th Floor, Boston, MA 02111, +1 617664 7581; Marti Subrahmanyam (msubrahm@stern.nyu.edu) is at the Stern School of Business, New York University, 44 West Fourth Street \# 9-15, New York, NY 10012, +1 2129980348.
\end{abstract}




\section{Abstract \\ The Determinants of Liquidity in the Corporate Bond Markets: An Application of Latent Liquidity}

We present a new measure of liquidity known as "latent liquidity" and apply it to a unique corporate bond database to discern the characteristics of bonds that lead to higher liquidity. Unlike conventional measures of liquidity, such as trading volume and bid-ask spreads, our measure of liquidity does not use transactional information; instead, it uses information about the ownership of securities to measure the accessibility of a security by a securities dealer. Therefore, our measure has the important advantage of being able to assess liquidity for markets with extremely low trading activity, where transactions data are insufficient to compute traditional measures of liquidity, but where liquidity is still an important issue. We relate our proposed latent liquidity measure to bond characteristics such as amount outstanding, credit quality, maturity, age, optionality and industry segment. In the liquid segments of the market, where trade-based measures of liquidity are available, our proposed measure exhibits similar relationships to bond characteristics as the trade-based measures. However, latent liquidity exhibits greater consistency in terms of its relationships with bond characteristics, over time. In addition, in the illiquid segment of the market, the relationships of our measure to bond characteristics are also similar to what we observe in the liquid segment. This leads us to believe that our measure is a viable measure of liquidity, when trade-based measures are unavailable. 


\section{Introduction}

Any investor holding a security or considering the purchase of a security is exposed to liquidity, or, more precisely, the lack of it. The conventional "reduced-form" definition of liquidity is the gap between the fundamental value of a security and the price at which the security is actually transacted: high liquidity implies that this gap is small, and vice versa. In this paper, our goal is to understand the determinants of liquidity and its cross-sectional variability in the context of relatively illiquid markets. However, while liquidity is easy to define in theoretical terms, its empirical measurement in an accurate and reliable manner is quite difficult, except in markets that are relatively very liquid. This is because most commonly used metrics of liquidity rely on transactional information, such as volume and trading spreads, with relatively high frequency, which are clearly unavailable when the asset in question is illiquid. For this reason, we first propose a measure for liquidity that does not require such transactions data. We call this measure latent liquidity, since it measures liquidity the way a typical "sell-side" dealer thinks about liquidity: it measures the accessibility of a security from sources where the security is currently being held. We apply this new measure of liquidity to try to understand the determinants of liquidity in one of the most well-known, but illiquid markets in the world - the market for U.S. corporate bonds.

Researchers have been developing theoretical models of liquidity for over two decades now. ${ }^{1}$ Indeed, this is a central concern of the market microstructure literature, which can broadly be split into two strands: models of information cost and models of inventory cost. Models based on information depend on the costs of trading against informed traders to generate a bid-ask spread. Copeland and Galai (1983) pioneered this literature in a one-trade framework, based on an insight provided by Bagehot (pseud.) (1971). This approach was then extended to sequential trade models by Glosten and Milgrom (1985) and Easley and O'Hara (1987), among others. The seminal paper by Kyle (1985) extended this literature considerably by incorporating the strategic behavior of an informed trader. Subsequently, papers by Admati and Pfeiderer (1988, 1989), Foster and Viswanathan (1990), and Seppi (1990) all extended this literature to consider the strategic behavior of uninformed (or liquidity) traders as well. Over the last fifteen years, a series

\footnotetext{
${ }^{1}$ Readers should consult O'Hara (2004) for a more thorough review of this literature.
} 
of information models have built on these fundamental papers and extended them to incorporate many other factors.

The first paper to consider inventory costs was by Garman (1976). Amihud and Mendelson (1980) extended Garman's model by incorporating inventory and time-variation of inventory (and its link to price changes). Stoll (1978) and Ho and Stoll (1981) instead approached the problem by analyzing the dealer's objective function in more detail. Specifically, they modelled the dealer as a provider of immediacy and focused on the required compensation for this service. Since then, aside from a few scattered papers such as O'Hara and Oldfield (1986), very little attention has been focused on the role of inventory costs in transactions prices, although it is recognized as a factor affecting liquidity and spreads.

The broad empirical issue of liquidity has been covered by many papers in both the equity and bond market literatures. For example, in the equity markets, questions receiving a great deal of attention recently are firstly, whether liquidity differentials explain the cross-sectional variation in returns, and secondly, whether liquidity risk is priced. ${ }^{2}$ Amihud and Mendelson (1986), Brennan and Subrahmanyam (1996), Brennan, Chordia and Subrahmanyam (1998), Datar, Naik, and Radcliffe (1998), Chordia, Roll, and Subrahmanyam (2000) have all found positive relationships between stock returns and overall liquidity as measured by spreads, depth, and volume. Meanwhile Chordia, Subrahmanyam and Anshuman (2001) find a negative relationship between liquidity and expected returns, while Hasbrouck and Seppi (2001) find no relationship. Finally, Huberman and Halka (2001) and Pastor and Stambaugh (2003) have examined the more relevant question of whether liquidity risk is a systematic factor.

Several authors have investigated alternative measures of liquidity, which do not rely on high-frequency data. Typically, these metrics rely only on daily volume and return data and can be related to Kyle's (1985) concept of

\footnotetext{
${ }^{2}$ Liquidity risk is the uncertainty of how wide or narrow the gap between fundamental value and the transactions price of a security will be at any point in time. For all investors, current and potential, liquidity risk is a real risk that they bear, and hence may be "priced," if it has a systematic component. Every transaction is essentially a negative NPV project for the "buy-side" investor, because she is always transacting at a price worse than the security's fundamental value. However, if the investor knew how negative the NPV would be, then this would not be a risk - the investor could simply perform his asset allocation optimization by factoring in the transaction costs. The risk comes from not knowing how far off the investor will transact in relation to the fundamental value of the asset she is buying or selling.
} 
the price impact of trading. Examples include the Amivest and the Amihud (2002) measures that are based on absolute return and trading volume. The relationship between these measures (and their variants) and microstructurebased measures has been investigated by Hasbrouck (2005) who shows that the Amihud measure is a robust measure of liqudity. Using this measure, Amihud (2002) shows there is an illiquidity premium in stock returns as the expected market illiquidity is correlated with stock excess return. Acharya and Pedersen (2005) also use this measure to investigate the various channels of the liquidity effect on stock returns in a unified liquidity-adjusted capital asset pricing model.

In the debt markets, much of the literature on liquidity has focused on the transactional characteristics of corporate debt. For example, Chakravarty and Sarkar (1999), Hong and Warga (2000), Schultz (2001), and Hotchkiss, Warga, and Jostava (2002) have all used the National Association of Insurance Commissioners (NAIC) database to study bid-ask spreads and trading volume in corporate bonds. Meanwhile Hotchkiss and Ronen (1999) and Alexander, Edwards, and Ferri (2000) have used the Fixed Income Pricing System (FIPS) database of high-yield bonds, collected by the National Association of Securities Dealers (NASD) to study various aspects of liquidity and informational efficiency in the corporate bond market.

The role of liquidity in the context of credit markets has been studied by several authors, who attempt to explain the yield spread on corporate bonds or credit default swaps. Several authors, including Duffee (1999), Duffie and Singleton (1997) Elton, Gruber, Agrawal and Mann (2001), Collin-Dufresne, Goldstein and Martin (2001), Huang and Huang (2003), Eom, Helwege and Huang (2004), Liu, Longstaff and Mandell (2004), and Longstaff, Mithal and Neis (2005), present evidence of non-default component of these spreads, and attribute at least part of it to illiquidity effects. However, in the absence of direct measures of liquidity for most corporate bonds, most researchers, so far, have been forced to rely on proxies such as age, notional amount oustanding, industry category, and credit risk. (In the case of the most liquid bonds, some data on bid-ask spreads is used, but this approach is clearly biased in favor of the most liquid bonds, given the lack of trading in most US corporate bonds, as we document below.) While these measure may be correlated with liquidity, it would be far better to obtain a more direct measure of liquidity, since these proxies may be quite imperfect.

A common feature among all the empirical papers written on liquidity, irrespective of the markets studied, is that they use transactions data, such as 
trading volume and the bid-ask spread, to measure liquidity. This approach is feasible in markets that are relatively liquid and have relatively continuous trading activity. However, this is not a realistic option, in general, since the most interesting markets to study liquidity, or more precisely, the lack of it, are those where liquidity is a problem, i.e., in asset markets that lack liquidity, such as the real estate market, the art market, the corporate bond market, to name a few. In general, most assets in these markets do not trade regularly; hence transactions data are very sparse, for all but a handful of the assets in these markets, since there is no trading activity for the bulk of the assets for several consecutive months. Any results from such studies are consequently skewed in the direction of the most liquid segment of these markets, and may not necessarily apply to the market as a whole. Hence, conventional measures of liquidity such as the bid-ask spread and trade count are difficult to employ in these markets, except for the most liquid assets in these markets. For example, in the US corporate bond market, the median bond trades much less than once every year, as compared with the US equity markets, where the median stock trades once every few minutes. Therefore, studies that use proxies of liquidity based on transactions data in these markets inevitably end up focusing on only the most liquid securities or markets - a classic case of looking for lost keys under the lamp post, where the light is shining, rather than where they were lost. Clearly, what is needed, therefore, is a measure of liquidity that does not rely on transactions data; such a measure would be ideal for studying liquidity in markets where the issue is of greatest interest - those that are relatively illiquid.

In order to address the question of liquidity in relatively illiquid markets, we construct a new liquidity measure that assesses the accessibility of a security, rather than its trading characteristics, and apply this measure to the US corporate bond market. ${ }^{3}$ Since corporate bonds trade in a dealer network, dealers rely on being able to access their "buy-side" clients' holdings either to purchase or sell bonds. If a bond is readily accessible, meaning a dealer can contact one of a number of "buy-side" clients and obtain the bond easily, the bond can be thought of as potentially liquid, even though it may not actually trade very much. Specifically, we conjecture that if a bond issue is held primarily by investors with high portfolio turnover, the bond may be

\footnotetext{
${ }^{3}$ We use the corporate bond market as an important example of an illiquid market, but it should be clear that the liquidity concepts and measures discussed here apply, more generally, to any security.
} 
thought of as more accessible - essentially, it is easier for a dealer to call one of the investors holding this bond and convince them to sell it at a reasonable spread in relation to its fundamental value. On the other hand, if a bond issue is held primarily by investors with extremely low portfolio turnover, such as long term buy-and-hold investors (e.g. insurance companies), it is more difficult for dealers to convince them to sell it. Thus, our measure of liquidity is based on a bond's accessibility. To apply this concept, we construct a statistic known as latent liquidity, which measures the accessibility of a bond to dealers, based on the aggregate trading characteristics of investors holding bonds. ${ }^{4}$

With a suitable measure of liquidity available, we then apply this measure to the US corporate bond market to determine the drivers of liquidity in this market. ${ }^{5}$ We analyze various characteristics of a bond, such as its credit rating, its maturity, etc., and determine whether or not each characteristic contributes to higher or lower liquidity, or accessibility, for that bond. Since the corporate bond market is essentially an over-the-counter market, with a large number of dealers, obtaining data on this market is quite difficult. No single dealer has enough market share, and, therefore, handles enough transactions for a meaningful analysis to be conducted. For this reason, our dataset comes from the world's largest custody bank, which holds data from a large number of "buy-side" clients. As part of their custody process, these banks record the transactions conducted by their clients; thus, the largest custody banks essentially "see" across the transactions databases of multiple dealers. While not being able to access data on all of the transactions in the corporate bond market, the largest custodians do record a substantial part of it. More importantly, the custodians become aware of only institutional rather than inter-dealer trading; thus, the database we use constitutes a more relevant portion of the trading universe (for the purpose of studying liquidity effects). As a result, the findings of the paper are much more appropriate for institutional trading and bond holdings.

In our empirical study, we find that the credit quality, the age of a bond,

\footnotetext{
${ }^{4}$ Our measure captures the "ease of buying" a particular bond. It does not directly measure the "ease of selling" the bond, since it does not measure the potential interest in such a bond. However, to the extent that holders of particular bonds may be interested in adding to their holdings, it measures the "ease of selling," albeit indirectly.

${ }^{5}$ Prior to the availability of transactions databases such as the NAIC or FIPS, studies typically employed yield spreads or issue size as proxies for liquidity. See, for example, Sarig and Warga (1989), Blume, Keim, and Patel (1991), and Crabbe and Turner (1995).
} 
the size of a bond issue, the original maturity value of a bond at issue date, and provisions such as a call, put, or convertible options all have a strong impact on liquidity. In these regressions, we use four different measures of liquidity as a dependent variable: our latent liquidity measure and three transaction-based measures, which are all alternative formulations of trading volume. We observe that when we restrict ourselves to the bonds in the database that have a relatively high degree of trading volume (because these are the only ones for which we can construct the transaction-based measures of liquidity), the results from the regressions are similar whether we use latent liquidity or the transaction-based measures. Along with the many tests we run on latent liquidity, this result gives us some comfort that the latent liquidity statistic appears to be a good proxy for liquidity. Furthermore, we also run the same empirical tests on the entire database (including the bonds that do not trade often enough for transaction-based liquidity measures to be calculated), and we find similar results. From this exercise, we conclude the following: when there is frequent trading and transactions data are available, our latent liquidity measure is as good as the transaction-based liquidity measures; so one can use any one of these measures. However, when there is infrequent trading and transaction-based measures simply cannot be calculated, our latent liquidity measure provides a good proxy for the liquidity of a security.

The organization of the paper is as follows. The second section introduces the database we use and provides some indications of how representative it is of the market as a whole, in terms of both holdings and transactions. It also provides some statistics on the trading frequency of bonds in our sample. This section also discusses the composition of the database in terms of various bond characteristics, such as issue size, age, maturity, industry segment etc. Finally, the section concludes with a precise definition of latent liquidity along with some graphs of the relationship between the proposed measure and key bond characteristics. In the third section, we present the results of a series of informal tests to check whether latent liquidity provides a good measure of liquidity. These tests relate the characteristics of bonds to both latent liquidity and two transaction-based measures of liquidity, for the most liquid segment of the market, where the latter measures can be constructed. We also present the results for the relationship between latent liquidity and the bond characteristics for the less liquid segment of our sample to provide a sense of how different these are are from the more liquid segment. The fourth section concludes. 


\section{Liquidity Measurement and Data}

While the corporate bond market appears to be an ideal market to study liquidity, particularly the drivers of liquidity, two primary reasons explain the lack of rigorous empirical research on liquidity in corporate bond markets. The first is that the corporate bond market is a dealer market (essentially an over-the counter (OTC) market); hence, no central data source exists for all the transactions occurring in the market. ${ }^{6}$ Therefore, it is difficult for any one entity to assemble a comprehensive bond transactions database of the whole market. The second problem relates to the computation of the metrics of liquidity. The definition of an illiquid market is that very little trading exists, often for several months at a time. Therefore, the question arises as to how to measure the degree of a corporate bond's illiquidity, i.e., what statistic can be used to proxy for a bond's illiquidity?

\subsection{The US Corporate Bond Database}

Since no single comprehensive source of trading data exists for the US corporate bond market as a whole, one has to rely on data from a sub-set of the market. One could go to an individual dealer and collect and analyze the transactions in which that dealer participates. However, this approach leaves open the possibility of biases: for example, a particular dealer might be a market leader in the high-yield segment of the market, in which case the database the researcher puts together from that dealer's transactions will be biased towards high-yield bonds. To avoid this problem, we use the databases of the world's largest custodian, State Street Corporation (SSC). The primary functions of a custodian are to provide trade clearance and settlement, the safekeeping of securities, and providing asset servicing such as dividend collection, proxy voting, and accounting and tax services. A custodian is not tied to any one dealer: its customers are the owners of assets, not the broker/dealers. Asset owners typically use multiple dealers to execute their

\footnotetext{
${ }^{6}$ The National Association of Securities Dealers (NASD) has initiated a program known as the Trade Reporting and Compliance Engine (TRACE), in which the individual members of the NASD report all of their corporate bond transactions. These transactions are aggregated into a common, market-wide database. However, the TRACE effort is not comprehensive, as yet; furthermore, because the program is relatively new, a reasonably long history will not be available for many years. More importantly, as we shall see later on, our measure of liquidity also requires information regarding the holdings of bonds by different investors. This is, clearly, not available in the TRACE database.
} 
transactions, but typically use one custodian for all their holdings. Since a custodian is not associated with any single dealer, its data aggregates transactions across multiple dealers. Therefore, the transactions database of a custodian should be much larger and more comprehensive than that of any one individual dealer; thus, the database is likely to be much more representative of the aggregate market, particularly relating to institutional investors. Furthermore, a custodian's database contains information about both transactions as well as the holdings of various investors, which will be used in combination in constructing our liquidity measure.

\subsection{A Comparative Analysis of the US Corporate Bond Database}

The SSB holdings database represents a comparatively large sample of the whole market for US corporate bonds in terms of both holdings as well as transactions. It also covers a relatively long history from January 1994 to December $2004 .^{7}$ We first present some evidence of the representative nature of the database in relation to the universe of US corporate bonds.

Table 1A presents the composition of the bonds in our database broken down by industry, as compared to the total universe of US corporate bonds. The universe is defined based on data from Reuters, for the amount of bonds outstanding, as of December 31, 2004. As can be seen from the table, which presents the amounts outstanding in the various industry categories, our total sample represents about $14.45 \%$ of the whole market. ${ }^{8}$ We can see from this table that our database provides a very good representation of the cross-section of bonds outstanding. The only deviation occurs with banks, which comprise $15.49 \%$ of our database, but represent only $12.16 \%$ of the total universe of bonds. In turn, our database is slightly underweighted in the electric power and manufacturing industries.

Table 1B presents a similar disaggregation of our data in relation to the universe of US corporate bonds, this time based on Moody's credit rating. Our database's credit quality composition exhibits a somewhat more deviation from the universe as compared to the industry composition in Table

\footnotetext{
${ }^{7}$ Unfortunately, some of the bond characteristics were not able in the database for the entire period. Consequently, we have restricted our empirical analysis to the period from January 1999 to December 2004.

${ }^{8}$ We use the industry categories defined by Reuters.
} 
1A. However, our database still remains reasonably representative of the universe, with our data being over-represented in the high quality (Aaa and Aa) segment $(7.55 \%$ and $19.92 \%$, in the SSB sample, respectively, compared with $5.72 \%$ and $16.19 \%$ in the universe) and under-represented in the low quality ( $\mathrm{C}$ and ungraded) segment (1.29\% and $2.88 \%$, respectively, compared with $3.10 \%$ and $6.55 \%$ in the universe). This is not surprising, considering that our holdings database consists of portfolios of institutional investors.

Table $1 \mathrm{C}$ presents the disaggregated statistics for our database in relation to the universe, based on maturity. Again, our database remains reasonably representative of the universe, although it is somewhat under-represented for the long maturities (greater than 10 years) - around $18.16 \%$ of the SSB sample, compared to $24.69 \%$ in the universe - and slightly over-represented for very short maturities (less than 1 year) - $18.89 \%$ in the SSB sample, as opposed to $15.46 \%$ in the whole market.

We turn next to the transaction statistics for our database versus the whole market, based on data from the Bond Market Association (BMA). ${ }^{9}$ This is presented in Table 2. We cannot draw conclusions about the representativeness of the trades in our database for the various cross-sections, due to the lack of comparable benchmarks for corporate bond transactions in the total universe. However, we do see that the database comprises over $9 \%$ of the average daily trading volume in US corporate bonds. ${ }^{10}$ Furthermore, this level does not fluctuate very much through time. The stability of trading volume gives some indication that the cross-sectional patterns, presented in Tables 1A, 1B and 1C, are fairly stable.

Based on the above comparisons, we can conclude that our database is reasonably representative of the whole market for US corporate bonds. This conclusion holds in terms of the broad characteristics of the bond market, both for the cross-sectional holdings of the bonds and the way this crosssection moves through time. We conjecture, therefore, that the conclusions we draw from this database should have relevance for the market as a whole.

\footnotetext{
${ }^{9}$ Unfortunately, this database does not provide transactions statistics disaggregated into the various categories mentioned earlier. Further, the statistics are available only on a monthly basis, and that too, only since January 2003.

${ }^{10}$ We believe that this figure may be on the conservative side, since we generally notice only one side of a trade, in our database, as opposed to both sides in the market, at large, had such data been available.
} 


\subsection{Characteristics of the US Corporate Bond Data- base}

Our goal in this paper is to conduct a broad analysis of the illiquidity in the US corporate bond market, based on the transactions in our database. Table 3 provides data on the illiquidity of the corporate bond market based on the frequency of trading to support our claim that this market is highly illiquid. We see from this table that, across the years, there are very few bonds that trade every day in our sample. The number of bonds that trade approximately every day (defined as over 200 days in the year) varies between 0 and 6; this is out of a sample of roughly 24,000 bonds. Even considering a level of trading of at least once a year as relatively liquid, the percentage of the total number of bonds in our sample that would be defined as liquid is between $25 \%$ and $30 \%$, each year. The vast majority of the bonds - over $70 \%$ - do not even trade once a year. These statistics throw some light on the problem of illiquidity in the corporate bond market and suggest that it would be futile to look for liquidity measures based only on market micro-structure data.

We now go into greater detail regarding the characteristics of the corporate bonds that are traded, based on our data set, over the period 1999-2004. We give an indication in Table 4 about the trading characteristics of corporate bonds that trade in the marketplace. In general, we see that bond issues are split into one of eight broad industry categories that we define (these are in line with the categories used by Reuters). The percentages in the various industry categories were fairly stable over the course of the 1999-2004 period. The financial services industry (the banks and the other financial categories) is the biggest issuer of corporate debt - in 2004, more than one-third of all new debt issues came from firms within this industry. This is not surprising, as most financial services firms such as banks and insurance companies are highly leveraged entities, with substantial debt obligations on the right-hand sides of their balance sheets.

Table 5 shows how the credit rating of bonds in the database has been changing through time. During the late 1990s, the database contained a higher percentage of investment grade bonds. For example, in 1999, 54\% of bond issues were rated as investment grade. As we progress through time, however, this proportion increased to $67 \%$ in 2004 . At the same time, the proportion of speculative grade bonds increased from 16\% in 1999 to $30 \%$ in 2004. There are two trends at work here. First, significant changes occurred 
in the marketplace, during this period. Equity markets dropped substantially during the early 2000s, indicating that the probability of default of most firms increased, as well. This conclusion is supported by the fact that credit spreads also increased significantly during this time period. Therefore, if rating agencies were doing a reasonable job, the conclusion that more bonds in the marketplace were getting rated below investment grade, is natural. Second, part of the changing picture is due to the fact that the proportion of bonds that were unrated declined over time, since rating agencies increased their coverage of corporate bonds. Although, many of these newly rated bonds fell into the speculative category, others were rated investment grade. Hence, the proportion of both investment and speculative grade bonds rose, while the proportion in the unrated category declined during this period.

We next present the data analyzed in terms of various bond characteristics such as maturity, time since issuance, face value and frequency of trading. We do this for each year, for data below each cumulative decile, during our sample period, 1999-2004. Table 6 displays the maturity structure of corporate debt in the marketplace. It is interesting to note that the average maturity of debt has been steadily decreasing through time. For example, the median bond in our data set has gone from an average 6.4 year maturity in 1999 to a 5.0 year maturity in 2004. Similarly, the maturity of the top decile dropped from 24.4 years in 1999 to 23.4 years in 2004, while that of the bottom decile remained unchanged between 1999 and 2004, at 1.1 years.

Table 7 shows that the time since issuance of outstanding debt has been steadily increasing from 1999 until the present. If we think of a time line for currently outstanding debt, there are two interesting points in time to consider: the first is when it was issued, relative to today, and the second is when it matures relative to today. From Table 6, we know that the time-to-maturity of the typical bond has decreased through time. However, from Table 7, we see that the time since the debt was issued has increased considerably through time. For the median security, it has gone from 1.7 years since issuance in 1999, to 4.3 years since issuance, in 2004. Similarly, for the top decile, it has gone from 6.8 years in 1999, to 8.9 years in 2004, while for the bottom decile increased from "when-issued" in 1999 to 1.2 years.

The explanation that reconciles these two facts is that the quantum of new debt issues has decreased through time, and firms have been financing themselves with shorter term debt than in the past. The decreasing number of debt issues means that the average debt issue in the marketplace is not getting replaced (refinanced); thus the time since issuance of the average 
debt issue is increasing. Furthermore, the debt that is getting refinanced is being replaced with instruments with shorter maturity, causing the average maturity of bonds outstanding to decrease. This is a surprising result given that interest rates during this time period were coming down, which would lead us to expect substantial new debt issuance and, therefore, causing the time since issuance statistic to decrease through time. Part of the explanation is the deleveraging of corporate balance sheets, that occurred following the stock market decline in 2000-2001. However, there is another factor at work here that explains part of this somewhat surprising result. We present this in the next table.

Table 8 shows the distribution of the outstanding face amount of all debt issues in the market. The table shows that the average face value amount has increased substantially over the last ten years. For the median bond, the face amount outstanding increased from \$ 150 million in 1999 to $\$ 272$ million in 2004. For the top decile, the corresponding numbers were $\$ 350$ million in 1999 going up to $\$ 950$ million in 2004; for the bottom decile, the face amount outstanding went up from $\$ 25$ million in 1999 to $\$ 100$ million in 2004. In reconciling this result with the results of the previous table, we see that while the number of new bond issues has been decreasing (as Table 7 shows), the face value of the average issuance must have been increasing substantially. This would account for the increased size of the average face value of debt remaining in the markets, over time. ${ }^{11}$ Thus, we seem to be observing the following financing trend: firms have been issuer fewer new bonds over time, but each new issuance has been larger than in the past, and of shorter maturity.

Table 9 gives us a sense of the amount of trading activity that occurs in the US corporate bond markets. Table 9, which is a variation of Table 3 , shows the average number of days that passes between trades for a bond issue, for those bonds that are actually traded. As shown in Table 3, most bonds did not have any trades for many years. We exclude them from the analysis presented in Table 9. For the median traded bond, the average time between trades declined from 103 days in 1999 to 58 days in $2004{ }^{12}$

\footnotetext{
${ }^{11}$ An alternative explanation is that the debt maturing through time had unusually small face value, thus causing the average face value of the remaining debt to increase. However, if this were the case, the total amount of debt outstanding would not increase, which indeed occurred. Furthermore, we would not expect to see increased daily trading volume (in dollars) through time, which we also observe.

${ }^{12}$ There are roughly twenty two trading days in a calendar month.
} 
For the bonds in the top decile, the time between trades remained virtually unchanged around 252 days.Even for the most liquid bonds in the bottom decile, liquidity improved during this period, with the time between trades dropping from 23 days in 1999 to 12 days in 2004. Despite the general improvement in liquidity in the corporate bond market, attested to by these statistics, the liquidity in this market, measured by the time between trades is much worse than in the stock market. For the median stock, in comparison, this value is more of the order of minutes. For the most liquid stocks, this statistic could even be of the order of seconds. Therefore, what we see from Table 9 is that the corporate bond market is orders of magnitude more illiquid than the stock market. An interesting point to emphasize is that despite the degree of illiquidity that currently exists in the corporate bond market, the current state of liquidity is much better than in prior years. Furthermore, this increase in trading is seen throughout the market, except in the most illiquid bonds. Thus, for most of the time period under investigation, even the median corporate bond (of all the bonds that traded at all during the year) has traded less than once every three months, which suggests that illiquidity is a central issue in this market.

\subsection{Liquidity Measurement}

The previous section provided strong evidence in support of the conclusion that the U.S. corporate bond market is extremely illiquid, although the degree of liquidity seems to be improving over the course of the five year period between 1999 and 2004. Therefore, in many ways, this seems a much more relevant setting to study the problems of illiquidity and its consequences, compared to equity markets, since this is a significant issue in the corporate debt market. However, one important problem remains. Most corporate bonds rarely trade. This makes it difficult to distinguish between whether a given bond is more liquid than another, particularly if both bonds do not trade for several days or even months. For example, if one bond trades six times a year and a second one trades three times a year, the amount of trading in both cases is too small to conclude that the first bond is twice as liquid as the second. A much more statistically reliable measure is needed beyond mere trade volume, or time between trades, to measure the liquidity of corporate bonds. To this end, we define a statistic called "latent liquidity" to measure the liquidity of any security that trades in a dealer market.

In a dealer, or OTC, market what really determines the liquidity of a 
security is the ease with which a dealer can access a security. For example, if a buy order comes in to a dealer, she could supply that order out of his own inventory, or she could try to source the bonds from the inventory of one of his other customers. In other words, the dealer could "work the order" by contacting customers to see if she can convince someone to sell him the bonds to fill the buy order. ${ }^{13}$ Consider the case when she is trying to call customers to fill the buy order. If the bond issue of interest is held primarily by funds with high turnover, it should be easier for the dealer to call one of these investors and convince the investor to sell him the needed bonds than if the bonds were held primarily by funds with low turnover (insurance companies, for example). ${ }^{14}$ This is because the high turnover funds are used to trading in and out of securities with high frequency, at least, relative to many fixed income investors, who tend to be "buy and hold till maturity" type of investors. Thus, they could be more easily convinced to trade a particular security they are holding. Therefore, whether a bond issue experiences a great deal of trading volume or not, we can say that a bond issue is more liquid in our sense, if it is more accessible by dealers. We define such access in terms of the turnover of the investors holding the bond issue.

This measure of accessibility of a security is not a direct measure of liquidity, but rather a more latent measure. In order to measure latent liquidity, we need to be able to determine, for each bond issue, which of the many types of investor holds the issue and the aggregated weighted average turnover of all the funds holding the issue. If the weighted average turnover of all the funds holding a particular bond issue is high, then we say that the bond issue has high latent liquidity. In other words, it is more accessible, relative to another bond that has lower latent liquidity. A bond's accessibility can be thought as the degree to which it is held by investors who are expected to trade more frequently, based on historical trading patterns.

Once again, a custodian is in an ideal position to obtain the information needed to calculate latent liquidity. Custodians are aware not only about the transactions level information but also the individual portfolio holdings. Therefore, if we look at the historical custodial holdings database, we can cal-

\footnotetext{
${ }^{13}$ The dealer will, of course, try to buy the bonds at a lower price from the customer than the price at which she will fill the buy order. Thus, she earns a fee for his "search services."

${ }^{14}$ Of course, one can define a whole continuum of customers, in terms of their propensity to trade, rather than the two referred to in the example.
} 
culate a twelve-month historical turnover number for all portfolios. For any particular bond issue, we aggregate across all the investors holding that issue, to calculate a weighted average turnover measure. This statistic becomes our latent liquidity measure for that particular bond.

More formally, we define the fractional holding of bond $i$ (as a percentage of the total outstanding amount of the bond issue in our database) by fund $j$ at the end of month $t$ as $\pi_{j, t}^{i}$. Also, we define the average portfolio turnover of fund $j$ from month $t$ to month $t-12$ as $T_{j, t}$, where the portfolio turnover is defined as the ratio of the value of fund $j$ at the end of month $t$ to the dollar trading volume of fund $j$ from month $t$ to month $t-12$. Latent liquidity for bond $i$ in month $t$ is defined as

$$
L_{t}^{i}=\sum_{j} \pi_{j, t}^{i} T_{j, t}
$$

Therefore, we define latent liquidity for any bond $i$, at any time $t$, as the aggregate weighted-average level of turnover of the individual funds holding bond $i$.

The most convenient feature of this measure is that it is based entirely on aggregate investors' holdings and does not require individual transaction details. In fact, as we have already said, the lack of sufficient corporate bond transaction data is at the heart of illiquidity in bond markets. Therefore, no trading in a particular bond needs to be observed in order to calculate this measure, which is especially convenient in the case of illiquid markets. Furthermore, this measure can be calculated quite accurately, on a monthly basis, for every public bond issue, given the unique nature of our database, which consists of data on both transactions, as well as holdings of a large set of investors in the market. It should be noted that even if a larger set of trading data eventually became available from the TRACE database, the metric we propose would require, in addition, information regarding the holdings of individual investors in the market, which is usually proprietary. It is unlikely, therefore, that our metric can be refined and extended further, using all the information available in the market.

Figures 1 through 5 present the patterns of changes in latent liquidity with respect to changes in certain bond characteristics, to show how they accord with more casually stated stylized facts. To generate these figures, after calculating a latent liquidity number for each US corporate bond in our database, we classified bonds into one of 5 groups segregated by quintiles, based on their latent liquidity, with bonds up to quintile 1 representing bonds 
with the highest latent liquidity and those just above quintile 5 representing bonds with the lowest latent liquidity. For each bond characteristic, the latent liquidity is averaged across bonds with a particular value of the characteristic. The graphs represent the relationship between the (average) latent liquidity and the particular bond characteristic.

Figure 1 plots the (average) latent liquidity of bonds in relation to their age, from the time they were first issued, until maturity. We observe that bonds are at their peak latent liquidity levels when they are just issued. Their latent liquidity level decreases steadily after issuance, until final maturity. This is consistent with, but more specific than, the casual evidence that "onthe-run" bonds are more liquid than their "off-the-run" counterparts. The conjecture that emerges is that many bonds are initially placed into high turnover funds, who then "flip" the bonds to lower turnover (usually, buyand-hold) funds. We see that latent liquidity values are greater than 2.5, on average, for bonds with an age of less than one year, and, in general, decrease over time to a value of less than 4, for bonds with an age greater than 26 years.

Figure 2 shows the relationship between (average) latent liquidity and issue size. Generally speaking, there is a positive correlation between issue size and liquidity. The biggest improvement in liquidity occurs for issue sizes below $\$ 600$ million. The liquidity is relatively flat again, until a size of $\$ 3$ billion is reached, when it increases once again. Figure 3 provides a plot of the (average) latent liquidity versus time to maturity for bond issues. We observe that the longer the maturity of the bond, the higher the latent liquidity, although there are clear jumps in the pattern, at certain maturity levels. The jumps in this figure are initially surprising, but easily explained - they are due to bond issues of "standard" maturities. For instance, bonds with a 10-year maturity are of two types: bonds that were issued in the past and are now down to 10 years to maturity i.e., "off-the-run" bonds and bonds that have just been issued i.e., "on-the-run" bonds. However, bonds with a 11-year maturity are likely composed of only "off-the-run" bonds (because 11 years is seldom chosen as a maturity time for newly-issued bonds). Therefore, the significantly higher latent liquidity of the "on-the-run" bonds at the 10year maturity level results in a substantially higher latent liquidity measure at the 10-year level vs. the 11-year level; hence, the observed jump in the graph. The same result holds at typical maturity points for new issues, such as at 5, 7, and 20 years, with the most pronounced jump occurring at the 10-year level, which is the most popular maturity for corporate bond issues. 
Figure 4 presents the (average) latent liquidity as a function of coupon rates over the sample period. There is no clear pattern in this relationship, because coupon effects are confounded by credit rating, age, maturity and issue date, since there are strong correlations between the coupon rate and these bond characteristics. In a loose sense, it appears that issues with a higher coupon rate enjoy greater liquidity than those with a lower coupon. However, there is a cyclical pattern to this relationship. At one extreme, it appears that zero coupon bonds are more liquid than bonds with a promised coupon rate of up to approximately $10 \%$. This may be due to the desirability of zero coupon issues for implementing hedging and cash matching strategies. At the other extreme, it appears that issues with very high coupon rates are more liquid than issues with lower coupon rates. In the relatively low interest rate environment that prevailed in 1999-2004, this translates into a statement that high premium bonds are more liquid than discount or par bonds. In between the relationship exhibits a cyclical pattern.

Figure 5 represents the (average) latent liquidity as a function of Moody's credit rating. We observe that latent liquidity is the lowest for A-rated bonds, and the highest for speculative grade bonds. This can be explained by the fact that insurance companies (which have low portfolio turnover) are typically overweighted in A-rated bonds. On the other hand, speculative grade bonds are concentrated among high turnover funds. These figures convey an intuitive sense of the relationship between latent liquidity and bond characteristics. However, since the relationship is inherently multi-factor in nature, with independet variables that are to some extent, correlated with each other, we need to examine it further through regression analysis. We turn to this empirical analysis next.

\section{Empirical Results}

In this section, we use our measure of latent liquidity to try to discern what features of a bond lead to better liquidity. To investigate this question, we conduct a series of regressions where the dependent variable is a metric of liquidity for a bond in the database at a point in time, while the independent variables are a set of the bond's characteristics. We conduct these regressions in three stages. In the first stage, we restrict ourselves to only those bonds where we see at least one trade per year (less than half the database, over time). Then, in the second stage, we use the entire universe of bonds. In 
the third and last stage, we conduct our analysis on the illiquid segment (the complement of the dataset used in the first stage) of our database, defined as bonds that had less than one trade a year.

In order to test/demonstrate the robustness of our liquidity measure, we will also compare the empirical results we obtain using latent liquidity against those obtained using more conventional trade-based measures of liquidity. The trade-based measures of liquidity require information about actual trades; therefore, for these measures, we are forced to restrict ourselves to the set of bonds for which we observe at least one trade per year. From our earlier tables, this means that we restrict ourselves to slightly less than half the database. We use three sets of trade-based liquidity measures for a bond. The first is trade days: the number of days per year that we see a particular bond trade. The second is trade count: the number of trades that we observe in our database for that particular bond per year. Finally, the third measure that we use is trade volume: the average market value of trades that we observe for the bond each year. For all of the trade-based liquidity measures that we use, we normalize the measures for each bond issue by dividing by the amount of that issue outstanding. This effectively allows us to control for issue size. Finally, for all the liquidity measures we consider (including latent liquidity), we convert the liquidity measures into a percentile rank within each year, since we interpret these measures to be ordinal, rather than cardinal, in nature.

We first examine the correlations between our measure of latent liquidity and the three trade-based measures of liquidity. Of course, this analysis can be undertaken only for the relatively liquid part of our database, the results of which are presented in Table 10. Only bonds that traded at least once in a given year were included in the sample. The correlations between the three trade-based measures are fairly high, as is to be expected, since they all measure the frequency and size of trades. However, the correlations between latent liquidity and the trade-based measures are more modest. Given the relatively infrequent trading in even the most liquid US corporate bonds, apparently the trade-based measures do not quite measure the same latent liquidity effects that are captured in our measure. We next investigate the relationship between the four measures and various characteristics of the bonds, in separate regressions, the results of which are presented in Tables 11 through 14 .

Table 11 presents results from the first of these regressions of these liquidity measures, on independent variables related to the characteristics of the 
bonds, in the relatively liquid (i.e., traded) segment of our database. These regressions were performed on a yearly basis for data from 1999 to 2004, as well as for the pooled sample for the whole period. Given the structural changes that occurred during the dot-com boom and subsequent collapse, we believe that the year-by-year results may be revealing. In this regression, we use latent liquidity (in percentile rank) as the dependent variable. In the tables that follow (Tables 12 to 14), we present the results from similar regressions for the other measures of liquidity. Latent liquidity values are as identified as of first trade date of year. These values are arranged in increasing order, for a given year and a percentile number is calculated. A higher liquidity percentile value indicates higher liquidity. All columns, but the last, present the coefficients and standard errors of a year-by-year regression. The last column presents the coefficients and standard errors for the data from 1999 to 2004 in a pooled regression. ${ }^{15}$

From the results of Table 11, we see that if a bond's issuer is classified as being either an industrial or a utility company, the bond tends to be less liquid, i.e., it tends to be held by low turnover funds. On the other hand, if a bond is from a financial issuer, there does not appear to be any effect on the liquidity of the bond. The credit quality of a bond appears to be inversely correlated to liquidity, i.e. the higher the probability of default (and therefore the lower the credit rating) the higher the degree of liquidity. This is a surprising result, because most people tend to associate high credit quality with high liquidity. The simple explanation here is that bonds that have a high credit quality are usually held by long-term "buy-and-hold" investors such as insurance companies, which have long-term liabilities and hold fixed income assets for asset-liability matching reasons, because these bonds are less likely to default and force a portfolio rebalancing. In addition, low-grade issues have a greater probability of rating migration, necessiating more frequent rebalancing.

As one might expect, the current age of the bond since issuance has a strong negative correlation with liquidity, i.e., a bond with a longer age (one that has been outstanding for a longer time) has less liquidity. This is

\footnotetext{
${ }^{15}$ The panel regressions have to be adjusted for the persistence of the independent variables. However, including the lagged values of the variables is problematic, in our case, since we have only five years of data. However, it should be noted that the standard errors reported in this and succeeding tables, are all biased downwards, and hence the corresponding $t$-statistics have to be interpreted with caution. We, therefore, introduce year dummies, which partly control for the persistence effects, albeit imperfectly
} 
the well known "on-the-run" vs. "off-the-run" effect (see for instance Sarig and Warga (1989), Warga (1992), Chakravarty and Sarkar (1999), Hong and Warga (2000), Schultz (2001), and Hotchkiss, Warga, and Jostava (2002)). When a bond is initially issued, it is "on-the-run" and has much higher liquidity than some time later, after it has been outstanding for a while and becomes "off-the-run".

The "original maturity" variables are all dummy variables indicating the maturity of the bond when it was issued. From the coefficients here, it appears that bonds with lower original maturity such as 5 and 7 years, are more liquid that those with an original maturity of 10 years. In turn, bonds that were originally of 10-year maturity tend to be more liquid than their 30-year counterparts. Again, one explanation here is that long term "buyand-hold" investors such as insurance companies (which hold a substantial amount of the total bonds outstanding) have long-dated liabilities, against which they match long-dated assets. Once they "find" these assets, they tend to hold them rather than trade them frequently.

Liquidity seems to be strongly correlated with the face amount of a bond outstanding, or the issue size of a bond. The larger the issue size, the more liquid is the bond. A preview of this result was illustrated in Figure 2, where we saw that when the size of the issue falls below $\$ 1$ billion, the smaller an issue size, the less liquid is the issuance. However, Figure 2 also showed that for amounts above $\$ 1$ billion, issue size seems to have only a small effect on liquidity. For smaller issue sizes, liquidity clearly diminishes with size. Smaller-sized issues do not appeal to a broad class of investors, since it would be difficult and costly to acquire a large position, which some institutional investors may require. The link between issue size and liquidity has also been identified by other researchers such as Hong and Warga (2000), Alexander, Edwards, and Ferri (2000), and Hotchkiss, Warga, and Jostava (2002).

Issuers generally have the choice of including various provisions into bond indentures. These provisions include option features that render the bond callable or puttable, making the bond convertible into equity, or providing for a sinking fund provision, in addition to various covenants. In our results, all these option features lead to an increase in a bond's liquidity. These results are surprising: one might think that adding complexity such as optionality to a bond would make it more difficult to trade, since the complexity may prevent less sophisticated investors from investing in these bonds, thus limiting the pool of potential investors. One should remember, however, that in a regime of volatile markets for equity and debt, such as the 1999-2004 period 
of our study, the option features of a bond require more frequent hedging, thereby increasing its turnover.

Other characteristics of a bond such as a sinking fund provision, whether the bond pays a fixed or floating coupon payment, or the periodicity of the coupon payments, do not seem to affect the liquidity of a bond in a systematic manner. However, if a bond has a zero coupon, this feature seems to increase its liquidity. As discussed previously, this may be due to the desirability of zero coupon issues for implementing hedging and cash matching strategies.

The last column of Table 11 provides the regression results for for the period 1999-2004, pooled across the years. It is interesting to note that the pooled regression simply sharpens the results from the year-by-year regressions. With more data, the standard errors of the coefficients decrease and the variables that were found to be statistically significant before, become even more so. The results remain completely consistent with the conclusions drawn from the year-by-year regressions.

Tables 12 to 14 present the same regressions as in Table 11, but with the latent liquidity dependent variable being replaced by the trade-based measures of liquidity: trade days, trade count, and trade market value. Exactly the same bonds, i.e. those that were part of the traded set, were used in all of the regressions in Tables 12 to 14, as in Table 11. The results in these tables, for the most part, are consistent with the findings in Table 11. However, the effects on liquidity seem to be sharper (more statistically significant) in the latent liquidity-based regressions. For example, the maturity effect disappears in all the trade-based liquidity regressions. The coefficients on the 5-year, 7-year, and 30-year dummy variables are all insignificant in the trade-based liquidity measures, though they come in strongly significant in the latent liquidity regression.

Intuitively, for the reasons given earlier, we expect the maturity effect to be an important determinant of liquidity. Also, in the case of latent liquidity based regression, liquidity seems to be strongly correlated with the face amount of a bond outstanding. This makes intuitive sense as discussed above. However, the relationship between amount outstanding and liquidity seems to be inconsistent across the other measures. It is weak to negative for trade days based regression, flips between positive and negative for trade count based regression and shows up as positively correlated for trade market value based regression. The results are also conflicting with respect to convertible features of bonds. As noted above, the frequent hedging, particularly by hedge funds, during uncertain market environment, can lead to 
more turnover for convertible bonds. The latent liquidity regression results are consistent with this hypothesis and shows a positive relationship between convertibility of a bond and its liquidity. However, the other measures show a negative relationship. One reason for the above anamolies in trade based regression results (Tables 12 through 14) might be that corporate bonds are extremely illiquid and trade very infrequently. Therefore, there is less statistical power in tests using trade-based measures, since many of the bonds do not trade very much.

Table 15 presents the same regression as in Table 11, but conducted on the entire State Street database of bonds, including bonds that did not trade at all in a given year. We cannot conduct this regression using the trade-based measures of liquidity, because more than half the bonds in the universe do not trade in any given year. However, because our latent liquidity measure does not require transaction data, this lack of trading poses no problems for conducting these regressions. The results in Table 15 are completely consistent with the results in Table 11, with the statistical significance increasing due to the use of substantially more data. As in the previous tables, the last column presents the results of regressions conducted on the pooled set of data from 1999-2004. We first observe that the results are completely consistent with the results from the year-by-year regressions. The credit quality of a bond is inversely correlated with liquidity in the overall sample, consistent with the results reported in Table 11. Similarly, the results are also consistent between Tables 11 and 15, with regard to bond age, original maturity, amount outstanding, optionality, the floating dummytime to maturity and the coupon rate. The suggests, that latent liquidity is a reasonable metric of liquidity even in the relatively illiquid part of the US corporate bond market, where trade-based measures of liquidity cannot be obtained.

In Table 16, we show the results of the pooled regression on the illiquid segment of the corporate bond universe. This set comprises of bonds for which we do not observe even one trade during a calendar year. ${ }^{16}$ Of course, this limits us to using a latent liquidity measure only. We compare the results to the pooled regression results (in the last column) of Table 10 which is based on the relatively liquid set, i.e. the set of bonds which had at least one trade during a calendar year. Between the two data sets, the directional

\footnotetext{
${ }^{16}$ This is essentially the complement of the restricted database, where we only considered bonds that had traded at least once during the calendar year. The results in Table 16 are from the other part of the dataset, and should, therefore, be compared with the first set of regressions presented in Table 11.
} 
relationships between latent liquidity and bond characteristic are completely consistent. (The minor exceptions being that in the case of illiquid set, the financial sector, sinkable and floating bond dummy flags, load up with statistical significance). This gives us a strong indication that latent liquidity measure can be extended to the illiquid segment of the US corporate bond market. The fact that latent liquidity is a consistent measure and does not have a sample bias, makes us believe that it can be used as a measure of liquidity uniformly across all the bonds in US corporate bond universe. It can be applied not only to the relatively liquid bonds where trade data is available but also to the illiquid segment of US corporate bond universe, where traditional trading data based measures cannot be obtained.

\section{Conclusion}

In conclusion, this paper presents a new measure of liquidity called latent liquidity, and we apply this measure to a unique corporate bond database to discern the characteristics of bonds that lead to higher liquidity. Unlike conventional measures of liquidity, such as trading volume and bid-ask spreads, latent liquidity does not use transaction information. Instead, it uses information about the ownership of securities to discern the accessibility of a security by a securities dealer. Therefore, latent liquidity has the important advantage in being able to provide a measure of liquidity in situations of low trading intensity, when transaction data are insufficient to compute traditional microstructure-based measures of liquidity but where liquidity is an important issue.

We apply the latent liquidity measure to a corporate bond database (corporate bonds are an extremely illiquid asset class) in order to determine the characteristics of corporate bonds that lead to higher or lower liquidity. We find that credit quality, the age of a bond, the size of a bond issue, the original maturity value of a bond at issuance date, and provisions such as a call, put, or convertible options all have strong impact on liquidity. If illiquidity is priced (i.e., investors charge a liquidity risk premium), then the results of this paper indicate that the design of a bond can have a strong influence on the cost of the bond to the issuer, and the choice of which bond to hold (from the same issuer) can have a strong influence on the returns of an investor.

The directional relationship between liquidity and the bond characteristics is compared across the various liquidity mesaures. For the most part, the 
results for latent liquidity agree with the three traditional measures based on transaction data. However, in certain cases such as original maturity of the bond, the face value outstanding and the optionality features of the bonds, latent liquidity seems to agree with intuitive reasoning, whereas the other measures do not always do so. We also determine that latent liquidity does not have a sample bias and can be used as a measure of liquidity uniformly across all the bonds in Corporate bond universe. It can be applied not only to the relatively liquid bonds where trade data is available but also to the illiquid segment of Corporate Bond universe, where transactional data is rare or unavailable and where traditional measures (based on transactional data) can not be applied with any statistical confidence.

We believe that this research can also pave the way to explain some portion of the yield spreads on corporate bonds that cannot be explained by structural models of corporate credit risk. In future research, we will investigate this directly by incorporating our liquidity factors in structural models of credit risk. It would also be interesting to examine the significance of liquidity in determining asset returns. In particular, we propose to use this measure in explaining the cross-sectional variation in bond yield spreads, over their Treasury and swap rate benchmarks, after accounting for default risk. Based on the evidence presented in this paper, it is likely that latent liquidity will explain at least part of the cross-sectional variation in bond yields, apart from the default premium. Our research will also address the issue of liquidity risk of corporate bonds, and whether or not, it is systematic in relation to the common liquidity. An additional question that we will attempt to examine is whether liquidity risk is, in fact, priced, and whether it is an important element of the total yield spread of corporate bonds over comparable Treasury bonds. 


\section{References}

- Acharya, V. V. and L. H. Pedersen (2005): "Asset pricing with liquidity risk", Journal of Financial Economics 77, 375-410.

- Admati, A. and P. Pfleiderer (1988): "A Theory of Intraday Patterns: Volume and Price Variability", Review of Financial Studies 1, 3-40.

- Admati, A. and P. Pfleiderer (1989): "Divide and Conquer: A Theory of Intraday and Day-of-the-Week Mean Effects", Review of Financial Studies 2, 189-224.

- Alexander, G., A. Edwards, and M. Ferri (2000): "The Determinants of the Trading Volume of High Yield Corporate Bonds", Journal of Financial Markets 3, 177-204.

- Assagai, S. and M. Gentler (1991): "Asset Returns and Transactions Cost and Uninsured Individual Risk: A Stage II Exercise", Journal of Monetary Economics 27, 309-331.

- Amihud, Y. (2002) : "Illiquidity and stock returns: cross-section and time series effects", Journal of Financial Markets 5, 31-56.

- Amihud, Y. and H. Mendelson (1980): "Dealership Market: Market Making with Inventory", Journal of Financial Economics 8, 31-53.

- Amihud, Y. and H. Mendelson (1986): "Asset Pricing and the Bid-Ask Spread", Journal of Financial Economics 17, 223-249.

- Amihud, Y. and H. Mendelson (1988): "Liquidity and Asset Prices: Financial Management Implications", Financial Management, Spring, $1-15$.

- Bagehot, W. (1971): "The Only Game in Town", Financial Analysts Journal 27, 12-14, 22.

- Balduzzi, P., S. Das, and S. Foresi (1998): "The Central Tendency: A Second Factor in Bond Yields", Review of Economics and Statistics 80, 60-72.

- Biais, B. (1993): "Price Formation and Equilibrium Liquidity in Fragmented and Centralized Markets", Journal of Finance 48, 157-185. 
- Blume, M.E., D.B. Keim, and S.A. Patel (1991): "Returns and volatility of low-grade bonds: 1977-1989", Journal of Finance 46, 49-74.

- Brennan, M., T. Chordia, and A. Subrahmanyam (1998): "Alternative Factor Specifications, Security Characteristics and the Cross-Section of Expected Stock Returns", Journal of Financial Economics 49, 345-373.

- Brennan, M. and A. Subrahmanyam (1996): "Market Microstructure and Asset Pricing: On the Compensation for Illiquidity in Stock Returns", Journal of Financial Economics 41, 441-464.

- Chacko, G. and E. Stafford (2004): "On the Costs of Capital Market Transactions", Working Paper, Harvard Business School.

- Chakravarty, S. and A. Sarkar (1999): "Liquidity in US Fixed Income Markets: A Comparison of the Bid-Ask Spread in Corporate, Government, and Municipal Bond Markets", Staff Report Number 73, Federal Reserve Bank of New York.

- Chen, R.R. and L. Scott (1992): "Pricing Interest Rate Options in a Two-Factor Model of the Term Structure and Its Applications in Pricing of Interest Rate Derivatives", Review of Financial Studies 5, 613-636.

- Chordia, T., R. Roll, and A. Subrahmanyam (2000): "Commonality in Liquidity", Journal of Financial Economics, 56, 3-28.

- Chordia, T., A. Subrahmanyam, V. Anshuman (2001): "Trading Activity and Expected Stock Returns", Journal of Financial Economics 59, 3-32.

- Pierre C.D., R.S. Goldstein, and J.S. Martin (2001): "The Determinants of Credit Spread Changes", Journal of Finance 56, 2177-2207.

- Crabbe, L. and C. Turner (1995): "Does the Liquidity of a Debt Issue Increase with its Size? Evidence from the Corporate Bond and Medium-Term Note Markets", Journal of Finance 50, 1719-1734.

- Constantinides, G. (1986): "Capital Market Equilibrium with Transaction Costs", Journal of Political Economy 94, 842-862. 
- Copeland, T. and D. Galai (1983): "Information Effects and the BidAsk Spread", Journal of Finance 38, 14571469.

- Datar, V., N. Naik, R. Radcliffe (1998): "Liquidity and Stock Returns: An Alternative Test", Journal of Financial Markets 1, 203-219.

- Demsetz, H. (1968): "The Cost of Transacting", Quarterly Journal of Economics LXXXII, 33-53.

- Duffee, G. R. (1999): "Forecasting future interest rates: Are affine models failures?", Working paper, U.C. Berkeley.

- Duffie, D. and K. Singleton (1997): "Modeling Term Structures of Defaultable Bonds", Review of Financial Studies Special 12, 687-720.

- Easley, D. and M. O' Hara (1987): "Price, Trade Size, and Information in Securities Markets", Journal of Financial Economics 19, 69-90.

- Easley, D. and M. O Hara (2001): "Information and the Cost of Capital", Working Paper, Cornell University.

- Easley, D., S. Hvidkjaer, and M. O' Hara (2002): "Is Information Risk a Determinant of Asset Returns", Journal of Finance 57, 2185-2222.

- Elton, E.J., M. Gruber, D. Agrawal and C. Mann (2001): "Explaining the Rate Spread on Corporate Bonds", Journal of Finance 56, 247-277.

- Eom, Y., H. J. Helwege, and J. Z. Huang (2004): "Structural models of corporate bond pricing: an empirical investigation", Review of Financial Studies 17, 499-544.

- Foster, F.D. and S. Viswanathan (1990): "A Theory of Intraday Variations in Volume, Variance, and Trading Costs in Securities Markets", Review of Financial Studies 3, 593-624.

- Garman, M. (1976): "Market Microstructure", Journal of Financial Economics 3, 257-275.

- Glosten, L. and P. Milgrom (1985): "Bid, Ask, and Transaction Prices in a Specialist Market with Heterogeneously Informed Traders", Journal of Financial Economics 14, 71-100. 
- Grossman, S. and M. Miller (1988): "Liquidity and Market Structure", Journal of Finance 43, 617-633.

- Grossman, S. and J. Stiglitz (1980): "On the Impossibility of Informationally Efficient Markets", American Economic Review 70, 393-408.

- Hasbrouck, J. and D. Seppi (2001): "Common Factors in Prices, Order Flows, and Liquidity", Journal of Financial Economics 59, 383-411.

- Hasbrouck, J. (2005): "Trading costs and returns for US equities: Evidence from daily data", Working Paper.

- Ho, T. and H. Stoll (1981): "Optimal Dealer Pricing Under Transactions and Return Uncertainty", Journal of Financial Economics 9, 47-73.

- Hong, G. and A. Warga (2000): "An Empirical Study of Bond Market Transactions", Financial Analysts Journal 56, 32-46.

- Hotchkiss, E. and T. Ronen: (1999): "The Informational Efficiency of the Corporate Bond Market: An Intraday Analysis", Working Paper, Boston College and Rutgers University.

- Hotchkiss, E., A. Warga, and G. Jostova (2002): "Determinants of Corporate Bond Trading: A Comprehensive Analysis", Working Paper, Boston College.

- Huang, J.Z. and M. Huang (2003): "How Much of the CorporateTreasury Yield Spread is Due to Credit Risk?", Working Paper, Penn State University.

- Huberman, G. and D. Halka (2001): "Systematic Liquidity", Journal of Financial Research 24, 161-178.

- Liu, J., F. A. Longstaff, and R. E. Mandell (2004): "The Market Price of Credit Risk: An Empirical Analysis of Interest Rate Swap Spreads", Forthcoming, Journal of Business.

- Longstaff, F. A. (1989): "A Nonlinear General Equilibrium Model of the Term Structure of Interest Rates", Journal of Financial Economics 2, 195-224. 
- Longstaff, F., S. Mithal, and E. Neis (2004), "Corporate Yield Spreads: Default Risk or Liquidity? New Evidence from the Credit-Default Swap Market", Forthcoming, Journal of Finance.

- Kyle, A. (1985): "Continuous auctions and insider trading", Econometrica 53, 1315-1335.

- Madhavan, A. and S. Smidt (1993): "An Analysis of Daily Changes in Specialist Inventories and Quotations", Journal of Finance 48, 189-210.

- Merton, R. (1974): "On the Pricing of Corporate Debt: The Risk Structure of Interest Rates", Journal of Finance 29, 449-470

- O' Hara, Maureen (2004): "Market Microstructure Theory", Blackwell Publishing, Oxford, UK.

- O' Hara, M. and G. Oldfield (1986): "The Microeconomics of Market Making", Journal of Financial and Quantitative Analysis 21, 361-376.

- Pastor, L. and R. Stambaugh (2003): "Liquidity Risk and Expected Stock Returns", Journal of Political Economy 111, 642-685.

- Sarig, O. and A. Warga (1989): "Bond Price Data and Bond Market Liquidity", Journal of Financial and Quantitative Analysis 24, 367-378.

- Schultz, P. (2001): "Corporate Bond Trading Costs: A Peak Behind the Curtain", Journal of Finance 56, 677-698.

- Seppi, D. (1990): "Equilibrium block trading and asymmetric information", Journal of Finance 45, 73-94.

- Stoll, H. (1978): "The Supply of Dealer Services in Securities Markets", Journal of Finance 33, 1133-1151.

- Vayanos, D. (1998): "Transaction Costs and Asset Prices: A Dynamic Equilibrium Model", Review of Financial Studies 11, 1-58.

- Vayanos, D. and J.-L. Vila (1999): "Equilibrium Interest Rates and Liquidity Premium with Transaction Costs", Economic Theory 13, 509539.

- Warga, A. (1992): "Bond Returns, Liquidity, and Missing Data", Journal of Financial and Quantitative Analysis 27, 605-617. 


\section{Table 1A: Composition of bonds outstanding in the State Street custody database, by Industry}

This table presents the composition, by industry category, as defined by Reuters, of US corporate bonds outstanding, as estimated by them, as of December 2004. This aggregate amount accounts for about $95 \%$ of the total US corporate bonds outstanding of $\$ 4,4704.5$ billion, based on the data of the Bond Market Association (BMA) at http://www.bondmarkets.com/story.asp?id=323. The first column defines the eleven industry categories, and the second and third columns define the amounts in billions of US dollars, of the total holdings in the markets for the universe of all issues, and for those issues where State Street Corporation served as custodian. The third and fourth columns show the relative amounts in percent for the eleven industry categories in the Reuters and State Street databases, respectively. The last column indicates the relative amount held by State Street, as a fraction of total US dollar amounts outstanding, in each industry category.

\begin{tabular}{llrlr}
\hline & $\begin{array}{l}\text { Total } \\
\text { Outstanding }\end{array}$ & \multicolumn{2}{l}{$\begin{array}{l}\text { State Street } \\
\text { Holdings }\end{array}$} \\
\hline Industry & & & & \\
\hline Banks & $\$$ & 545 & $\$$ & 100 \\
Consumer Goods & $\$$ & 145 & $\$$ & 21 \\
Electric Power & $\$$ & 319 & $\$$ & 40 \\
Energy Company & $\$$ & 216 & $\$$ & 32 \\
Gas Distribution & $\$$ & 22 & $\$$ & 3 \\
Independent Finance & $\$$ & 26 & $\$$ & 3 \\
Manufacturing & $\$$ & 624 & $\$$ & 82 \\
Other Financial & $\$$ & 1,529 & $\$$ & 221 \\
Service Company & $\$$ & 662 & $\$$ & 92 \\
Telephone & $\$$ & 302 & $\$$ & 42 \\
Transportation & $\$$ & 95 & $\$$ & 14 \\
& & & & \\
\hline Total & $\$$ & 4,485 & $\$$ & 648 \\
\hline
\end{tabular}

\begin{tabular}{ll}
\hline Total & State Street \\
Outstanding & Holdings \\
\hline As \% Of & As \% Of \\
Total & Total \\
\hline 12.16 & 15.49 \\
3.23 & 3.20 \\
7.10 & 6.10 \\
4.82 & 4.87 \\
0.48 & 0.48 \\
0.58 & 0.41 \\
13.91 & 12.68 \\
34.08 & 34.06 \\
14.77 & 14.14 \\
6.74 & 6.46 \\
2.13 & 2.11 \\
& \\
\hline 100 & 100 \\
\hline
\end{tabular}

\begin{tabular}{l}
\hline State Street \\
Holdings \\
\hline As \% Of \\
Total Outstanding \\
\hline 18.41 \\
14.32 \\
12.42 \\
14.61 \\
14.47 \\
10.17 \\
13.17 \\
14.44 \\
13.83 \\
13.85 \\
14.33 \\
\hline 14.45
\end{tabular}


Table 1B: Composition of bonds outstanding in the State Street custody database, by credit rating

This table presents the composition, by credit rating, as defined by Moody's, of US corporate bonds outstanding, as estimated by Reuters, as of December 2004. This aggregate amount accounts for about $95 \%$ of the total US corporate bonds outstanding of $\$ 4,4704.5$ billion, based on the data of the Bond Market Association (BMA) at http://www.bondmarkets.com/story.asp?id=323. The first column defines the nine credit rating categories, and the second and third columns define the amounts in billions of US dollars, of the total holdings in the markets for the universe of all issues, and for those issues where State Street Corporation served as custodian. The third and fourth columns show the relative amounts in percent for the nine credit rating categories in the Reuters and State Street databases, respectively. The last column indicates the relative amount held by State Street, as a fraction of total US dollar amounts outstanding, in each credit rating category.

\begin{tabular}{llrlr}
\hline & $\begin{array}{l}\text { Total } \\
\text { Outstanding }\end{array}$ & \multicolumn{2}{l}{$\begin{array}{l}\text { State Street } \\
\text { Holdings }\end{array}$} \\
\hline Credit Rating & & & & \\
\hline Aaa & $\$$ & 257 & $\$$ & 49 \\
Aa & $\$$ & 726 & $\$$ & 129 \\
A & $\$$ & 1,071 & $\$$ & 148 \\
Baa & $\$$ & 1,071 & $\$$ & 152 \\
Ba & $\$$ & 325 & $\$$ & 48 \\
B & $\$$ & 430 & $\$$ & 71 \\
Caa & $\$$ & 173 & $\$$ & 24 \\
C & $\$$ & 139 & $\$$ & 8 \\
Other or NA Grade & $\$$ & 294 & $\$$ & 19 \\
& & & & \\
\hline Total & $\$$ & 4,485 & $\$$ & 648 \\
\hline
\end{tabular}

\begin{tabular}{ll}
\hline Total & State Street \\
Outstanding & Holdings \\
\hline As \% Of & As \% Of \\
Total & Total \\
\hline 5.72 & 7.55 \\
16.19 & 19.92 \\
23.88 & 22.83 \\
23.88 & 23.51 \\
7.25 & 7.37 \\
9.58 & 10.94 \\
3.86 & 3.70 \\
3.10 & 1.29 \\
6.55 & 2.88 \\
\hline 100 & 100 \\
\hline
\end{tabular}

\begin{tabular}{l}
\hline State Street \\
Holdings \\
\hline As \% Of \\
Total Outstanding \\
\hline 19.08 \\
17.78 \\
13.82 \\
14.23 \\
14.69 \\
16.51 \\
13.86 \\
6.03 \\
6.35 \\
\hline 14.45 \\
\hline
\end{tabular}


Table 1C: Composition of bonds outstanding in the State Street custody database, by maturity

This table presents the composition, by maturity, of US corporate bonds outstanding, as estimated by Reuters, as of December 2004 . This aggregate amount accounts for about $95 \%$ of the total US corporate bonds outstanding of $\$ 4,4704.5$ billion, based on the data of the Bond Market Association (BMA) at http://www.bondmarkets.com/story.asp?id=323. The first column defines the thirteen maturity categories, and the second and third columns define the amounts, in billions of dollars of the total holdings in the markets, for the universe of all issues, and for those issues where State Street Corporation served as custodian. The third and fourth columns show the relative amounts in percent for the thirteen maturity categories in the Reuters and State Street databases, respectively. The last column indicates the relative amount held by State Street, as a fraction of total US dollar amounts outstanding, in each maturity category.

\begin{tabular}{llrlr}
\hline & $\begin{array}{l}\text { Total } \\
\text { Outstanding }\end{array}$ & \multicolumn{2}{l}{$\begin{array}{l}\text { State Street } \\
\text { Holdings }\end{array}$} \\
\hline Time To Maturity & & & & \\
\hline$<=1$ Year & $\$$ & 693 & $\$$ & 122 \\
2 Years & $\$$ & 436 & $\$$ & 67 \\
3 Years & $\$$ & 391 & $\$$ & 49 \\
4 Years & $\$$ & 337 & $\$$ & 44 \\
5 Years & $\$$ & 296 & $\$$ & 40 \\
6 Years & $\$$ & 324 & $\$$ & 49 \\
7 Years & $\$$ & 288 & $\$$ & 49 \\
8 Years & $\$$ & 236 & $\$$ & 42 \\
Y Years & $\$$ & 222 & $\$$ & 42 \\
Between 11 and 15 Years & $\$$ & 154 & $\$$ & 27 \\
Between 16 and 30 Years & $\$$ & 245 & $\$$ & 24 \\
$>$ 30 Years & $\$$ & 807 & $\$$ & 89 \\
& & 56 & $\$$ & 4 \\
\hline Total & $\$$ & 4,485 & $\$$ & 648 \\
\hline
\end{tabular}

\begin{tabular}{ll}
\hline Total & State Street \\
Outstanding & Holdings \\
\hline As \% Of & As \% Of \\
Total & Total \\
\hline 15.46 & 18.89 \\
9.72 & 10.40 \\
8.72 & 7.49 \\
7.50 & 6.82 \\
6.61 & 6.15 \\
7.22 & 7.53 \\
6.43 & 7.56 \\
5.25 & 6.44 \\
4.96 & 6.45 \\
3.43 & 4.10 \\
5.46 & 3.66 \\
17.99 & 13.81 \\
1.24 & 0.69 \\
\hline 100 & \\
\hline
\end{tabular}

\begin{tabular}{l}
\hline State Street \\
Holdings \\
\hline As \% Of \\
Total Outstanding \\
\hline 17.65 \\
15.47 \\
12.41 \\
13.13 \\
13.45 \\
15.06 \\
17.01 \\
17.73 \\
18.80 \\
17.31 \\
9.71 \\
11.09 \\
8.01 \\
\hline 14.45 \\
\hline
\end{tabular}


Table 2: Comparision of trade volume between State Street Custody compared to the whole market

This table presents statistics for the monthly traded volume (in billions of US dollars) of US Corporate bonds for the entire market versus the amount traded in the State Street Corporation's custody holdings database, during the period January 2003 to December 2004 . Only securities greater than one year to maturity are considered. The aggregate market statistics is provided by Bond Market Association (BMA) at http://www.bondmarkets.com/story.asp?id=96. The first two columns indicate the date. The third and fourth columns indicate the average daily par quantity traded in the State Street database, and in the market, respectively. The last column indicates the ratio of the amount traded from State Street holdings to that for the entire market (expressed as a percentage).

\begin{tabular}{|c|c|c|c|c|}
\hline $\begin{array}{l}\text { Trade } \\
\text { Year }\end{array}$ & $\begin{array}{l}\text { Trade } \\
\text { Month }\end{array}$ & $\begin{array}{l}\text { Average Daily Trade Volume } \\
\text { in State Street Custody Holdings } \\
\text { (in billions of US Dollars) }\end{array}$ & $\begin{array}{l}\text { Average Daily Trade Volume in } \\
\text { Market } \\
\text { (in billions of US Dollars) }\end{array}$ & $\begin{array}{l}\text { Average Daily Trade Volume in } \\
\text { State Street Custody Holdings } \\
\text { (as a \% of Market) }\end{array}$ \\
\hline 2003 & January & 2.21 & 22.9 & $9.65 \%$ \\
\hline 2003 & February & 2.06 & 21.8 & $9.46 \%$ \\
\hline 2003 & March & 2.15 & 23.4 & $9.19 \%$ \\
\hline 2003 & April & 2.09 & 20.5 & $10.19 \%$ \\
\hline 2003 & May & 2.12 & 23 & $9.20 \%$ \\
\hline 2003 & June & 1.83 & 22 & $8.31 \%$ \\
\hline 2003 & July & 1.88 & 20.3 & $9.25 \%$ \\
\hline 2003 & August & 1.57 & 15.4 & $10.21 \%$ \\
\hline 2003 & September & 2.00 & 23.8 & $8.40 \%$ \\
\hline 2003 & October & 1.90 & 20.2 & $9.41 \%$ \\
\hline 2003 & November & 1.89 & 20 & $9.45 \%$ \\
\hline 2003 & December & 1.60 & 16 & $10.02 \%$ \\
\hline 2004 & January & 2.16 & 25 & $8.65 \%$ \\
\hline 2004 & February & 2.02 & 22 & $9.17 \%$ \\
\hline 2004 & March & 2.20 & 22.7 & $9.70 \%$ \\
\hline 2004 & April & 1.84 & 19.8 & $9.31 \%$ \\
\hline 2004 & May & 1.83 & 18.4 & $9.96 \%$ \\
\hline 2004 & June & 1.67 & 20.1 & $8.33 \%$ \\
\hline 2004 & July & 1.91 & 20.6 & $9.29 \%$ \\
\hline 2004 & August & 1.58 & 20.6 & $7.67 \%$ \\
\hline 2004 & September & 1.99 & 21.1 & $9.43 \%$ \\
\hline 2004 & October & 1.89 & 22.3 & $8.48 \%$ \\
\hline 2004 & November & 1.85 & 22.7 & $8.15 \%$ \\
\hline 2004 & December & 1.56 & 19.4 & $8.07 \%$ \\
\hline
\end{tabular}


Table 3: Trade distribution by the frequency of trading

This table presents statistics for the distribution of issues by frequency of trade, of US Corporate dollar denominated bonds, in the State Street Corporation's custody trades database, during the period 1999-2004. The frequency of trading of an issue is defined as number of distinct trading days in a given year. The data shows the number of issues corresponding to a particular trading frequency in each year. For example, in 2003, 6 issues traded more than 200 days and 37 issues traded between 150 and 200 days.

\begin{tabular}{lllllll}
\hline Frequency of Trading & $\mathbf{1 9 9 9}$ & $\mathbf{2 0 0 0}$ & $\mathbf{2 0 0 1}$ & $\mathbf{2 0 0 2}$ & $\mathbf{2 0 0 3}$ & $\mathbf{2 0 0 4}$ \\
\hline$>200$ days in year & 0 & 0 & 2 & 5 & 6 & 3 \\
$>$ 150 days in year & 1 & 6 & 6 & 21 & 37 & 23 \\
$>$ 100 days in year & 7 & 21 & 33 & 114 & 126 & 115 \\
$>$ 50 days in year & 84 & 169 & 220 & 404 & 566 & 596 \\
$>$ 30 days in year & 205 & 303 & 368 & 480 & 609 & 732 \\
$>$ 10 days in year & 1184 & 1347 & 1346 & 1462 & 1512 & 1842 \\
$>5$ days in year & 1185 & 1160 & 1186 & 1068 & 1056 & 1222 \\
At least 1 day in year & 3473 & 3332 & 2910 & 2610 & 2515 & 2673 \\
No trades in year & 18502 & 17307 & 16096 & 15382 & 15467 & 16988 \\
& & & & & & 21894 \\
\hline Total Issues & 24641 & 23645 & 22167 & 21546 & 24194 \\
\hline
\end{tabular}


Table 4: Trade distribution by industry sector

This table presents the distribution of trade market value, by industry sector, as defined by Reuters, of US Corporate dollar denominated bonds, in the State Street Corporation's custody trades database, during the period 1999-2004. The trading distribution of a given industry sector is expressed as a percentage of total market value of trades, for the given year, within the State Street custody database.

\begin{tabular}{lllllll}
\hline Industry Sector & $\mathbf{1 9 9 9}$ & $\mathbf{2 0 0 0}$ & $\mathbf{2 0 0 1}$ & $\mathbf{2 0 0 2}$ & $\mathbf{2 0 0 3}$ & $\mathbf{2 0 0 4}$ \\
\hline Banks & 12 & 12 & 12 & 11 & 11 & 11 \\
Consumer Goods & 4 & 3 & 3 & 4 & 4 & 4 \\
Electric Power & 7 & 7 & 7 & 7 & 8 & 8 \\
Energy Company & 5 & 6 & 6 & 6 & 6 & 6 \\
Gas Distribution & 1 & 1 & 1 & 1 & 1 & 1 \\
Independent Finance & 1 & 1 & 1 & 1 & 1 & 0 \\
Manufacturing & 16 & 15 & 14 & 15 & 17 & 17 \\
Other Financial & 30 & 30 & 30 & 28 & 28 & 28 \\
Service Company & 16 & 15 & 15 & 17 & 17 & 18 \\
Telephone & 7 & 7 & 7 & 6 & 5 & 5 \\
Transportation & 3 & 3 & 3 & 3 & 3 & 3 \\
\hline Total & & 100 & 100 & 100 & 100 & 100 \\
\hline
\end{tabular}


Table 5: Trading distribution by credit rating

This table presents the distribution of trade market value, by credit rating, as defined by Moody's of US corporate dollar denominated bonds, in the State Street Corporation's custody trades database, during the period 1999-2004. The trading distribution of a given credit rating is expressed as percentage of total market value of trades, for the given year, within the State Street's custody trades database.

\begin{tabular}{lllllll}
\hline Credit Rating & $\mathbf{1 9 9 9}$ & $\mathbf{2 0 0 0}$ & $\mathbf{2 0 0 1}$ & $\mathbf{2 0 0 2}$ & $\mathbf{2 0 0 3}$ & $\mathbf{2 0 0 4}$ \\
\hline Aaa & 2 & 3 & 3 & 4 & 4 & 4 \\
Aa & 10 & 10 & 11 & 11 & 11 & 11 \\
A & 26 & 29 & 27 & 25 & 25 & 27 \\
Baa & 16 & 18 & 18 & 20 & 22 & 25 \\
Below Baa & 16 & 18 & 17 & 21 & 26 & 30 \\
Other or NA Grade & 30 & 22 & 24 & 19 & 12 & 3 \\
\hline Total & 100 & 100 & 100 & 100 & 100 & 100 \\
\hline
\end{tabular}


Table 6: Percentile distribution of trades, by maturity (in years)

This table presents the distribution of maturity, in years, of trades in US corporate dollar denominated bonds, in the State Street Corporation's custody trades database, during the period 1999-2004. The maturity of a bond is defined as the years remaining to maturity. Bonds that trade in a given year, are sorted in the order of increasing maturity, and the decile cutoff values are computed. The value shown is the maturity of the bond at the given percentile. For example, the data shows that the median trade had a time to maturity of 6.4 years in 1999 and 5 years in 2004 .

\begin{tabular}{lllllll}
\hline Percentile & $\mathbf{1 9 9 9}$ & $\mathbf{2 0 0 0}$ & $\mathbf{2 0 0 1}$ & $\mathbf{2 0 0 2}$ & $\mathbf{2 0 0 3}$ & $\mathbf{2 0 0 4}$ \\
\hline 10 & 1.1 & 1 & 1 & 1 & 1 & 1.1 \\
20 & 2.1 & 1.7 & 1.8 & 2 & 2.1 & 2 \\
30 & 3.4 & 2.8 & 2.9 & 3.2 & 3.1 & 3.1 \\
40 & 4.9 & 4 & 4.2 & 4.5 & 4.4 & 4 \\
50 & 6.4 & 5.3 & 5.4 & 5.6 & 5.3 & 5 \\
60 & 8 & 7 & 6.9 & 6.9 & 6.7 & 6.5 \\
70 & 9.3 & 8.3 & 8.2 & 8.7 & 8.8 & 8.1 \\
80 & 10.1 & 10 & 10 & 10 & 12.1 & 12.2 \\
90 & 24.4 & 23.5 & 23.6 & 24 & 23.9 & 23.4 \\
\hline
\end{tabular}


Table 7: Percentile distribution of trades, by age (in years)

This table presents the distribution of age, in years, of trades in US corporate dollar denominated bonds, in the State Street Corporation's custody trades database, during the period 1999-2004. The age of a bond is defined as the number of years since its issue. Bonds that trade in a given year, are sorted in the order of increasing age, and the decile cutoff values are computed. The value shown is the age of the bond at the given percentile. For example, the data shows that the median trade had an age of 1.7 years in 1999 and 4.3 years in 2004 .

\begin{tabular}{lllllll}
\hline Percentile & $\mathbf{1 9 9 9}$ & $\mathbf{2 0 0 0}$ & $\mathbf{2 0 0 1}$ & $\mathbf{2 0 0 2}$ & $\mathbf{2 0 0 3}$ & $\mathbf{2 0 0 4}$ \\
\hline & when- & when- & when- & when- & & \\
10 & issued & issued & issued & issued & 0.2 & 1.2 \\
20 & 0.2 & 0.6 & 0.5 & 0.4 & 0.8 & 1.7 \\
30 & 0.7 & 1.2 & 1.3 & 1.2 & 1.6 & 2.4 \\
40 & 1.1 & 1.7 & 2.1 & 2.2 & 2.6 & 3 \\
50 & 1.7 & 2.2 & 2.8 & 3.2 & 3.8 & 4.3 \\
60 & 2.4 & 2.9 & 3.4 & 4 & 4.7 & 5.2 \\
70 & 3.4 & 3.9 & 4.3 & 4.8 & 5.5 & 6 \\
80 & 5.2 & 5.4 & 5.9 & 6.3 & 6.8 & 7 \\
90 & 6.8 & 7.5 & 8.3 & 8.9 & 9.3 & 8.9 \\
\hline
\end{tabular}


Table 8: Percentile distribution of trades, by face value (millions of US dollars)

This table presents the distribution of face value (in millions of US Dollars) of trades in US corporate dollar denominated bonds, in the State Street Corporation's custody trades database, during the period 1999-2004. The face value of a bond is defined as the amount outstanding on the trade date. Bonds that trade in a given year, are sorted in the order of increasing face amount and the decile cutoff values are computed. The value shown is the average face value of the bond for the given percentile. For example, the data shows that the median trade had a face value of 150 million dollars in 1999 and 272 million dollars in 2004.

\begin{tabular}{lllllll}
\hline Percentile & $\mathbf{1 9 9 9}$ & $\mathbf{2 0 0 0}$ & $\mathbf{2 0 0 1}$ & $\mathbf{2 0 0 2}$ & $\mathbf{2 0 0 3}$ & $\mathbf{2 0 0 4}$ \\
\hline 10 & 25 & 25 & 35 & 50 & 70 & 100 \\
20 & 60 & 75 & 99 & 100 & 100 & 150 \\
30 & 100 & 100 & 100 & 135 & 150 & 200 \\
40 & 110 & 125 & 150 & 153 & 200 & 227 \\
50 & 150 & 150 & 175 & 200 & 220 & 272 \\
60 & 180 & 200 & 200 & 250 & 260 & 300 \\
70 & 200 & 250 & 250 & 300 & 316 & 400 \\
80 & 250 & 300 & 302 & 400 & 500 & 500 \\
90 & 350 & 450 & 500 & 600 & 750 & 950 \\
\hline
\end{tabular}


Table 9: Percentile distribution of trades, by time elapsed between successive trades (in days)

This table presents the distribution of time elapsed between trades (in days) of trades in US corporate dollar denominated bonds, in the State Street Corporation's custody trades database during the period 1999-2004. The time elapsed is defined as the number of days between successive trades of a given bond. Bonds that trade in a given year, are sorted in the order of increasing time elapsed and the decile cutoff values are computed. The values shown are the average time elapsed of the bond for the given percentile range. For example, the data shows that the median trade had a elapsed time of 103 days in 1999 between successive trades and 58 days in 2004.

\begin{tabular}{lllllll}
\hline Percentile & $\mathbf{1 9 9 9}$ & $\mathbf{2 0 0 0}$ & $\mathbf{2 0 0 1}$ & $\mathbf{2 0 0 2}$ & $\mathbf{2 0 0 3}$ & $\mathbf{2 0 0 4}$ \\
\hline 10 & 23 & 20 & 15 & 12 & 11 & 12 \\
20 & 38 & 35 & 26 & 20 & 18 & 19 \\
30 & 55 & 52 & 40 & 31 & 28 & 28 \\
40 & 76 & 74 & 59 & 47 & 43 & 41 \\
50 & 103 & 100 & 83 & 69 & 62 & 58 \\
60 & 134 & 131 & 114 & 95 & 88 & 85 \\
70 & 192 & 175 & 147 & 133 & 128 & 123 \\
80 & 252 & 252 & 251 & 249 & 199 & 171 \\
90 & 252 & 252 & 251 & 252 & 252 & 253 \\
\hline
\end{tabular}




\section{Figure 1. Latent liquidity rating as a function of bond age}

This figure presents the pattern of changes in the latent liquidity with respect to age of bond (in years), of trades in US corporate dollar denominated bonds, in the State Street Corporation's custody trades database, during the period 1999-2004. The latent liquidity of a bond is defined as the aggregate weighted-average level of turnover of the investors holding the bond. The age of a bond is defined as the number of years since issue. The values of the latent liquidity rating vary between 1 and 5, where 1 represents the highest liquidity level and 5 the lowest liquidity level.

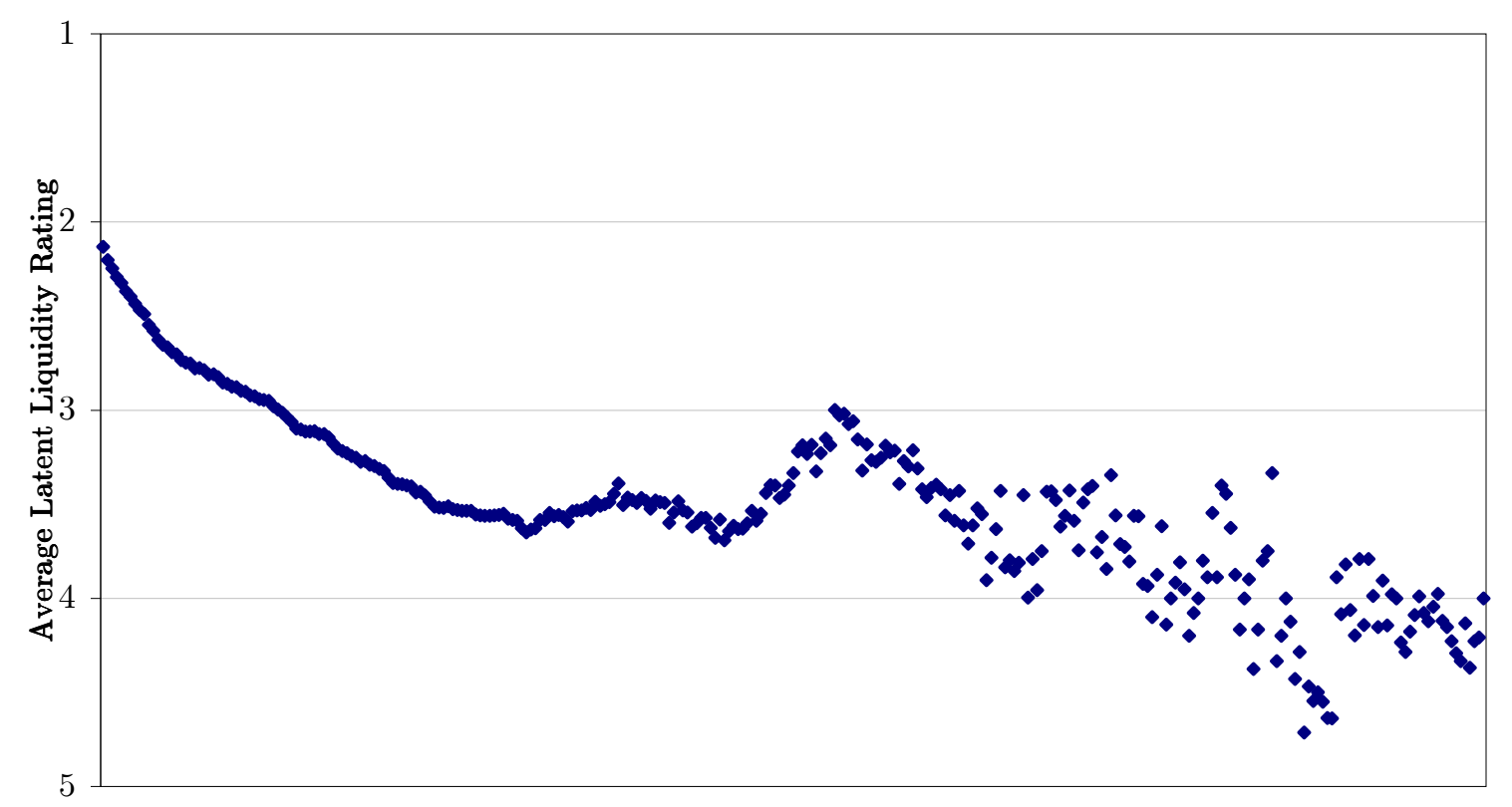

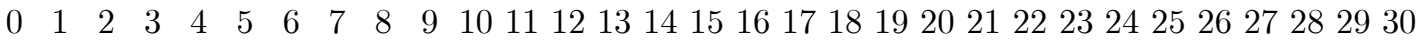
Age - (Years Since Issuance) 


\section{Figure 2. Latent liquidity rating as a function of issue size}

This figure presents the pattern of changes in latent liquidity with respect to issue size (in billions of US Dollars), of trades in US corporate dollar denominated bonds, in the State Street Corporation's custody trades database, during the period 1999-2004. The latent liquidity of a bond is defined as the aggregate weighted-average level of turnover of the investors holding the bond. The values of the latent liquidity rating vary between 1 and 5 , where 1 represents the highest liquidity level and 5 the lowest liquidity level. Issue size is defined as the amount of principal at issuance.

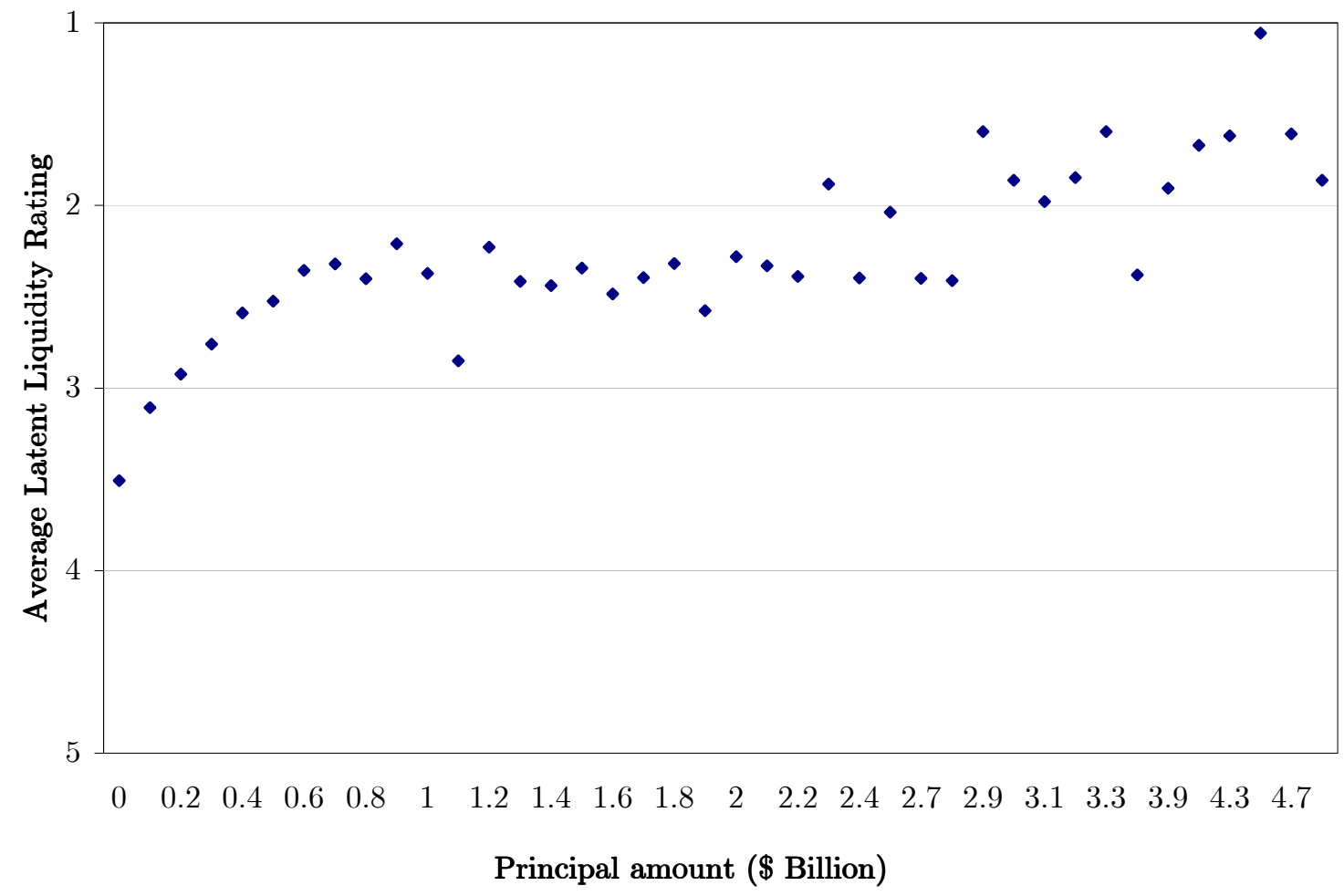


Figure 3. Latent liquidity as a function of maturity

This figure presents the pattern of changes in latent liquidity with respect to time to maturity (in years), of trades in US corporate dollar denominated bonds, in the State Street Corporation's custody trades database database, during the period 1999-2004. The latent liquidity of a bond is defined as the aggregate weighted-average level of turnover of the investors holding the bond. The age of a bond is defined as the number of years since the issue date. The values of the latent liquidity rating vary between 1 and 5 , where 1 represents the highest liquidity level and 5 the lowest liquidity level.

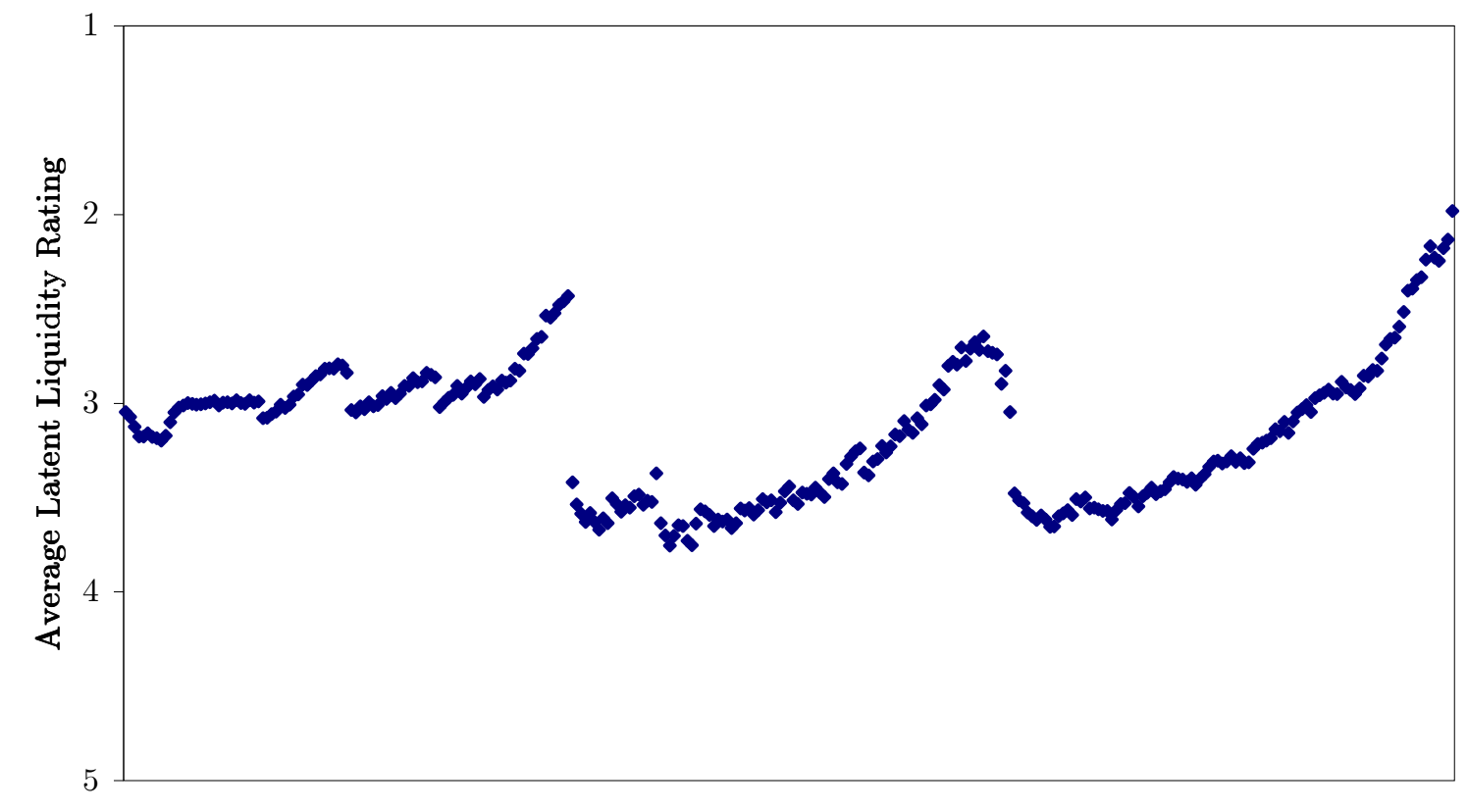

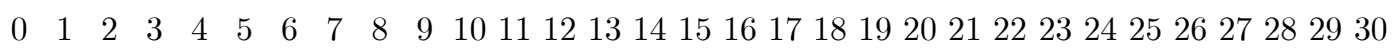

Average Time To Maturity (Years) 


\section{Figure 4. Latent liquidity as a function of coupon}

This figure presents the pattern of changes in latent liquidity with respect to coupon (in \%) of trades in US corporate dollar denominated bonds, in the State Street Corporation's custody trades database database, during the period 1999-2004. The latent liquidity of a bond is defined as the aggregate weighted-average level of turnover of the investors holding the bond. The coupon is defined as the annual payment in relation to the principal amount of the bond. The values of the latent liquidity rating vary between 1 and 5 , where 1 represents the highest liquidity level and 5 the lowest liquidity level.






\section{Figure 5: Latent Liquidity as a function of Moodys rating categories}

This figure gives the average value of latent liquidity for various Moody's Credit rating categories, in US corporate dollar denominated bonds, in the State Street Corporation's custody trades database, during the period 1999-2004. The latent liquidity of a bond is defined as the aggregate weighted-average level of turnover of the investors holding the bond. The values of the latent liquidity rating vary between 1 and 5 , where 1 represents the highest liquidity level and 5 the lowest liquidity level.

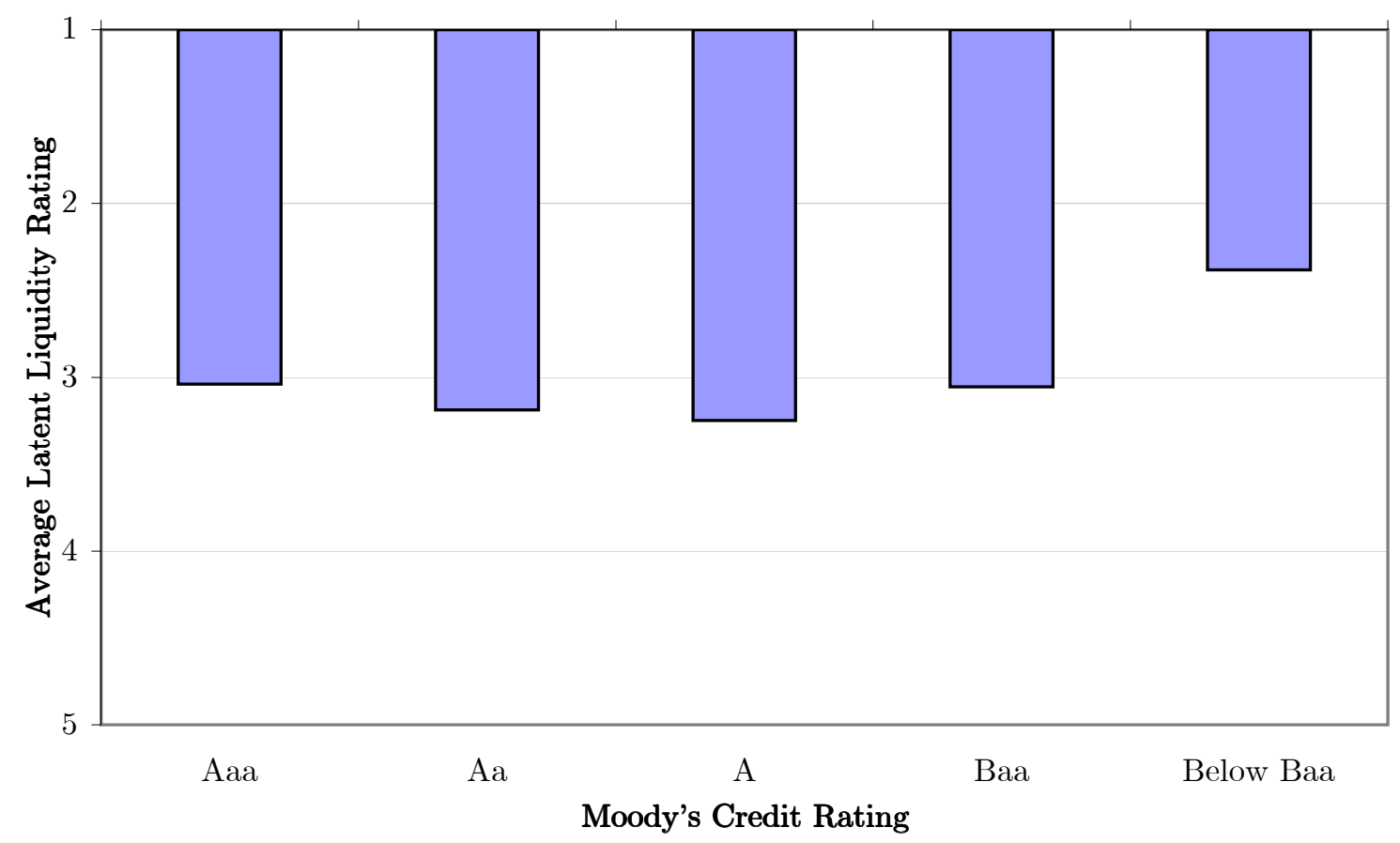




\section{Table 10: Correlation between various Liquidity Measures}

This table presents the correlation between the various measures of liquidity. The measures of liquidity are latent liquidity, trade days, trade count and traded market value. Each of the the measures is expressed as a percentile. These variables are calculated from a set of US corporate bonds, that traded at least once during a calendar year, in the State Street Corporation's custody trades database. To calculate the latent liquidity percentile, latent liquidity values are identified as of first trade date of year. These values are arranged in increasing order, for a given year and a percentile number is calculated. A higher latent liquidity percentile value indicates higher liquidity. To calculate the number of trade days percentile, we first divide the number of trades for the given issue in the given year, by the amount outstanding as of the first trade day for that year. These normalized values are arranged in increasing order, for a given year and a percentile number is calculated. A higher trade days percentile value indicates higher liquidity. To calculate the trade count percentile (the dependent variable), we first divide the number of trades for the given issue in the given year, by the amount outstanding as of the first trade day for that year. These normalized values are arranged in increasing order, for a given year and a percentile number is calculated. A higher trade count percentile value indicates higher liquidity. To calculate the trade market value percentile, we first divide the total market value of trades for the given issue in the given year, by the amount outstanding as of the first trade day for that year. These normalized values are arranged in increasing order, for a given year and a percentile number is calculated. A higher trade market value percentile value indicates higher liquidity.

\begin{tabular}{l|llll}
\hline & Latent Liquidity & Trade Days & Trade Count & Traded Market Value \\
\hline Latent Liquidity & 1.00 & 0.33 & 0.34 & 0.27 \\
Trade Days & & 1.00 & 0.99 & 0.72 \\
Trade Count & & 1.00 & 0.73 \\
Traded Market Value & & & 1.00 \\
\hline
\end{tabular}


Table 11: Liquidity regression on the traded set using latent liquidity as the measure of liquidity

This table presents the results of a multiple regression where latent liquidity (expressed as a percentile) is the dependent variable. The numbers in each cell represent the regression coefficients for the independent variables in the first column with the $t$-statistic in parenthesis. The independent variables are shown in the first column under the heading regression variables. The credit rating is Moody's rating represented as a quintile (number 1 through 5), with Aaa being 1 and below Baa3 being 5 . These variables are identified as of the first trade of the year. The regression analysis is performed each year for a set of US corporate bonds that traded at least once during the year, in the State Street Corporation's custody trades database. The last column provides the results for the sample pooled across the years 1999-2004. To calculate the latent liquidity percentile (the dependent variable), latent liquidity values are identified as of first trade date of year. These values are arranged in increasing order, for a given year and a percentile number is calculated. A higher latent liquidity percentile value indicates higher liquidity.

\begin{tabular}{|c|c|c|c|c|c|c|c|}
\hline Regression Variables & 1999 & 2000 & 2001 & 2002 & 2003 & 2004 & 1999-2004 \\
\hline Constant & $\begin{array}{l}0.354 \\
(12.469)\end{array}$ & $\begin{array}{l}0.435 \\
(15.480)\end{array}$ & $\begin{array}{l}0.382 \\
(13.263)\end{array}$ & $\begin{array}{l}0.365 \\
(13.525)\end{array}$ & $\begin{array}{l}0.32 \\
(12.547)\end{array}$ & $\begin{array}{l}0.2 \\
(8.980)\end{array}$ & $\begin{array}{l}0.327 \\
(28.551)\end{array}$ \\
\hline Industrial Sector (dummy) & $\begin{array}{l}-0.048 \\
(-4.146)\end{array}$ & $\begin{array}{l}-0.013 \\
(-1.075)\end{array}$ & $\begin{array}{l}-0.052 \\
(-4.217)\end{array}$ & $\begin{array}{l}-0.051 \\
(-4.588)\end{array}$ & $\begin{array}{l}-0.054 \\
(-5.051)\end{array}$ & $\begin{array}{l}-0.029 \\
(-2.876)\end{array}$ & $\begin{array}{l}-0.041 \\
(-8.855)\end{array}$ \\
\hline Financial Sector (dummy) & $\begin{array}{l}0.001 \\
(\mathbf{0 . 0 4 9 )}\end{array}$ & $\begin{array}{l}0.026 \\
\mathbf{( 1 . 9 9 9 )}\end{array}$ & $\begin{array}{l}-0.013 \\
(-0.987)\end{array}$ & $\begin{array}{l}-0.007 \\
(-0.622)\end{array}$ & $\begin{array}{l}-0.013 \\
(-1.102)\end{array}$ & $\begin{array}{l}-0.005 \\
(-0.425)\end{array}$ & $\begin{array}{l}-0.002 \\
(-0.330)\end{array}$ \\
\hline Utility Sector (dummy) & $\begin{array}{l}-0.056 \\
(-3.903)\end{array}$ & $\begin{array}{l}-0.02 \\
(-1.351)\end{array}$ & $\begin{array}{l}-0.015 \\
(-1.061)\end{array}$ & $\begin{array}{l}-0.033 \\
(-2.446)\end{array}$ & $\begin{array}{l}-0.023 \\
(-1.758)\end{array}$ & $\begin{array}{l}-0.012 \\
(-0.972)\end{array}$ & $\begin{array}{l}-0.024 \\
(-4.198)\end{array}$ \\
\hline Credit Rating (Moodys) rank & $\begin{array}{l}0.027 \\
(5.228)\end{array}$ & $\begin{array}{l}0.007 \\
(1.447)\end{array}$ & $\begin{array}{l}-0.003 \\
(-0.606)\end{array}$ & $\begin{array}{l}0.015 \\
(3.418)\end{array}$ & $\begin{array}{l}0.032 \\
(7.205)\end{array}$ & $\begin{array}{l}0.071 \\
(17.437)\end{array}$ & $\begin{array}{l}0.028 \\
(\mathbf{1 4 . 9 4 1 )}\end{array}$ \\
\hline Age of Bond in years & $\begin{array}{l}-0.022 \\
(-18.092)\end{array}$ & $\begin{array}{l}-0.022 \\
(-17.422)\end{array}$ & $\begin{array}{l}-0.017 \\
(-14.473)\end{array}$ & $\begin{array}{l}-0.021 \\
(-16.163)\end{array}$ & $\begin{array}{l}-0.022 \\
(-16.983)\end{array}$ & $\begin{array}{l}-0.021 \\
(-19.040)\end{array}$ & $\begin{array}{l}-0.021 \\
(-42.291)\end{array}$ \\
\hline Original Maturity 5 year (dummy) & $\begin{array}{l}0.091 \\
(6.218)\end{array}$ & $\begin{array}{l}0.098 \\
\mathbf{( 7 . 3 5 3 )}\end{array}$ & $\begin{array}{l}0.091 \\
(6.862)\end{array}$ & $\begin{array}{l}0.077 \\
(6.263)\end{array}$ & $\begin{array}{l}0.086 \\
\mathbf{( 7 . 3 0 6 )}\end{array}$ & $\begin{array}{l}0.071 \\
(6.424)\end{array}$ & $\begin{array}{l}0.084 \\
(16.428)\end{array}$ \\
\hline Original Maturity 7 year (dummy) & $\begin{array}{l}0.068 \\
(5.050)\end{array}$ & $\begin{array}{l}0.045 \\
(3.220)\end{array}$ & $\begin{array}{l}0.049 \\
(\mathbf{3 . 4 8 3})\end{array}$ & $\begin{array}{l}0.037 \\
(2.751)\end{array}$ & $\begin{array}{l}0.034 \\
(2.566)\end{array}$ & $\begin{array}{l}0.067 \\
(5.383)\end{array}$ & $\begin{array}{l}0.051 \\
(\mathbf{9 . 2 3 6 )}\end{array}$ \\
\hline Original Maturity 30 year (dummy) & $\begin{array}{l}-0.095 \\
(-6.651)\end{array}$ & $\begin{array}{l}-0.042 \\
(-2.730)\end{array}$ & $\begin{array}{l}-0.048 \\
(-3.147)\end{array}$ & $\begin{array}{l}-0.023 \\
(-1.574)\end{array}$ & $\begin{array}{l}-0.048 \\
(-3.433)\end{array}$ & $\begin{array}{l}-0.013 \\
(-0.981)\end{array}$ & $\begin{array}{l}-0.046 \\
(-7.698)\end{array}$ \\
\hline Amount Outstanding (\$Billions) & $\begin{array}{l}0.007 \\
(0.491)\end{array}$ & $\begin{array}{l}0.03 \\
(2.136)\end{array}$ & $\begin{array}{l}0.031 \\
(2.147)\end{array}$ & $\begin{array}{l}0.122 \\
(8.610)\end{array}$ & $\begin{array}{l}0.1 \\
(7.248)\end{array}$ & $\begin{array}{l}0.076 \\
(5.979)\end{array}$ & $\begin{array}{l}0.06 \\
(10.660)\end{array}$ \\
\hline Callable (dummy) & 0.077 & 0.036 & 0.036 & 0.034 & 0.008 & -0.048 & 0.019 \\
\hline
\end{tabular}


Table 11: Liquidity regression on the traded set using latent liquidity as the measure of liquidity (conitinued)

\begin{tabular}{|c|c|c|c|c|c|c|c|}
\hline Regression Variables & 1999 & 2000 & 2001 & 2002 & 2003 & 2004 & 1999-2004 \\
\hline & $(7.937)$ & $(3.812)$ & $(3.863)$ & $(3.750)$ & $(0.970)$ & $(-6.211)$ & $(5.126)$ \\
\hline \multirow{2}{*}{ Putable (dummy) } & 0.081 & 0.085 & 0.116 & 0.094 & 0.082 & 0.101 & 0.092 \\
\hline & $(3.444)$ & $(3.425)$ & $(4.528)$ & $(3.777)$ & $(3.321)$ & $(4.120)$ & $(9.170)$ \\
\hline \multirow[t]{2}{*}{ Convertible (dummy) } & 0.1 & 0.056 & 0.203 & 0.147 & 0.172 & 0.072 & 0.129 \\
\hline & $(3.792)$ & $(1.850)$ & $(7.169)$ & $(5.461)$ & $(6.877)$ & $(2.734)$ & $(11.964)$ \\
\hline \multirow[t]{2}{*}{ Sinkable (dummy) } & 0.043 & 0.021 & -0.005 & 0.025 & -0.002 & -0.014 & 0.011 \\
\hline & $(1.823)$ & $(0.876)$ & $(-0.206)$ & $(1.143)$ & $(-0.100)$ & $(-0.633)$ & $(1.242)$ \\
\hline \multirow[t]{2}{*}{ Float (dummy) } & -0.006 & -0.075 & 0.044 & 0.004 & -0.016 & 0.029 & -0.002 \\
\hline & $(-0.246)$ & $(-3.235)$ & $(1.915)$ & $(0.187)$ & $(-0.731)$ & $(1.732)$ & $(-0.225)$ \\
\hline \multirow{2}{*}{ Not semi-annual coupon (dummy) } & 0.01 & 0.006 & 0.097 & 0.032 & 0.07 & 0.071 & 0.05 \\
\hline & $(0.417)$ & $(0.264)$ & $(4.261)$ & $(1.579)$ & $(3.586)$ & $(4.244)$ & $(5.948)$ \\
\hline \multirow[t]{2}{*}{ Time to Maturity in years } & 0.001 & 0 & 0 & 0 & 0 & 0 & 0 \\
\hline & $(2.185)$ & $(0.459)$ & $(0.581)$ & $(0.137)$ & $(0.089)$ & $(0.296)$ & $(1.987)$ \\
\hline \multirow[t]{2}{*}{ Coupon } & 0.011 & 0.009 & 0.02 & 0.011 & 0.013 & 0.014 & 0.012 \\
\hline & $(4.097)$ & $(3.380)$ & $(7.487)$ & $(4.339)$ & $(5.389)$ & $(6.382)$ & $(11.930)$ \\
\hline$\overline{\text { Adj-R2 }}$ & 0.184 & 0.111 & 0.118 & 0.158 & 0.173 & 0.191 & 0.144 \\
\hline $\mathrm{R} 2$ & 0.188 & 0.114 & 0.121 & 0.160 & 0.176 & 0.193 & 0.144 \\
\hline $\mathrm{F}$ & 61.996 & 37.909 & 40.148 & 58.948 & 69.339 & 87.530 & 242.266 \\
\hline$p$-Value & 0.000 & 0.000 & 0.000 & 0.000 & 0.000 & 0.000 & 0.000 \\
\hline Number of observations & 4585 & 5012 & 4968 & 5265 & 5548 & 6225 & 31603 \\
\hline
\end{tabular}


Table 12: Liquidity regression on the traded set using trade days as the measure of liquidity

This table presents the results of a multiple regression where number of trade days (expressed as a percentile) is the dependent variable.The numbers in each cell represent the regression coefficients for the independent variables in the first column with the $t$-statistic in parenthesis. The independent variables are shown in the first column under the heading Regression Variables. The credit rating is Moody's rating represented as a quintile (number 1 through 5), with Aaa being 1 and below Baa3 being 5 . These variables are identified as of first trade of year. The regression analysis is performed each year for a set of US corporate bonds that traded at least once during the year, in the State Street Corporation's custody trades database. The last column provides the results for the sample pooled across the years 1999-2004. To calculate number of trade days percentile (the dependent variable), we first divide the number of trades for the given issue in the given year, by the amount outstanding as of the first trade day for that year. These normalized values are arranged in increasing order, for a given year and a percentile number is calculated. A higher trade days percentile value indicates higher liquidity.

\begin{tabular}{llllllll}
\hline Regression Variables & 1999 & 2000 & 2001 & 2002 & 2003 & 2004 & $1999-2004$ \\
\hline Constant & 0.438 & 0.337 & 0.425 & 0.315 & 0.245 & 0.31 & 0.337 \\
& $(16.420)$ & $(12.930)$ & $(15.873)$ & $(12.769)$ & $(10.649)$ & $(14.881)$ & $(31.849)$ \\
Industrial Sector (dummy) & -0.034 & -0.043 & -0.054 & -0.057 & -0.041 & -0.035 & -0.045 \\
& $(-3.127)$ & $(-3.896)$ & $(-4.712)$ & $(-5.591)$ & $(-4.305)$ & $(-3.780)$ & $(-10.607)$ \\
Financial Sector (dummy) & -0.048 & -0.038 & -0.067 & -0.069 & -0.051 & -0.05 & -0.053 \\
& $(-4.035)$ & $(-3.100)$ & $(-5.492)$ & $(-6.315)$ & $(-4.896)$ & $(-5.012)$ & $(-11.615)$ \\
Utility Sector (dummy) & -0.057 & -0.06 & -0.086 & -0.142 & -0.097 & -0.088 & -0.088 \\
& $(-4.286)$ & $(-4.347)$ & $(-6.360)$ & $(-11.402)$ & $(-8.327)$ & $(-7.710)$ & $(-17.018)$ \\
Credit Rating (Moodys) rank & 0.067 & 0.071 & 0.063 & 0.077 & 0.084 & 0.086 & 0.076 \\
& $(13.962)$ & $(15.103)$ & $(13.825)$ & $(18.835)$ & $(21.124)$ & $(22.526)$ & $(43.503)$ \\
Age of Bond in years & -0.016 & -0.013 & -0.014 & -0.014 & -0.019 & -0.021 & -0.016 \\
& $(-13.705)$ & $(-11.143)$ & $(-12.599)$ & $(-11.845)$ & $(-16.616)$ & $(-19.918)$ & $(-35.117)$ \\
Original Maturity 5 year (dummy) & 0.004 & 0.017 & -0.006 & -0.005 & -0.017 & -0.007 & 0.003 \\
& $(0.297)$ & $(1.377)$ & $(-0.526)$ & $(-0.430)$ & $(-1.598)$ & $(-0.652)$ & $(0.590)$ \\
Original Maturity 7 year (dummy) & -0.012 & 0.006 & 0.019 & 0.003 & 0.008 & 0.025 & 0.009 \\
& $(-0.914)$ & $(0.465)$ & $(1.436)$ & $(0.258)$ & $(0.707)$ & $(2.113)$ & $(1.765)$ \\
Original Maturity 30 year (dummy) & -0.064 & -0.039 & -0.006 & 0.01 & -0.009 & 0.004 & -0.018 \\
& $(-4.777)$ & $(-2.784)$ & $(-0.396)$ & $(0.712)$ & $(-0.737)$ & $(0.293)$ & $(-3.192)$ \\
Amount Outstanding (\$Billions) & -0.185 & -0.119 & -0.132 & -0.035 & -0.003 & 0.014 & -0.074 \\
& $(-14.207)$ & $(-9.160)$ & $(-9.988)$ & $(-2.741)$ & $(-0.241)$ & $(1.139)$ & $(-14.334)$ \\
Callable (dummy) & 0.061 & 0.041 & 0.057 & 0.049 & 0.034 & -0.001 & 0.04 \\
& $(\mathbf{6 . 6 9 2})$ & $(4.616)$ & $(6.467)$ & $(5.994)$ & $(4.377)$ & $(-0.078)$ & $(11.647)$
\end{tabular}


Table 12: Liquidity regression on the traded set using trade days as the measure of liquidity (continued)

\begin{tabular}{|c|c|c|c|c|c|c|c|}
\hline Regression Variables & 1999 & 2000 & 2001 & 2002 & 2003 & 2004 & 1999-2004 \\
\hline \multirow[t]{2}{*}{ Putable (dummy) } & -0.029 & -0.046 & -0.004 & -0.041 & -0.052 & -0.042 & -0.053 \\
\hline & $(-1.337)$ & $(-1.990)$ & $(-0.182)$ & $(-1.810)$ & $(-2.334)$ & $(-1.830)$ & $(-5.697)$ \\
\hline \multirow[t]{2}{*}{ Convertible (dummy) } & 0.048 & -0.014 & -0.043 & -0.124 & -0.098 & -0.155 & -0.072 \\
\hline & $(1.933)$ & $(-0.508)$ & $(-1.651)$ & $(-5.033)$ & $(-4.324)$ & $(-6.308)$ & $(-7.247)$ \\
\hline \multirow[t]{2}{*}{ Sinkable (dummy) } & 0.013 & -0.065 & -0.108 & -0.092 & -0.095 & -0.034 & -0.066 \\
\hline & $(0.584)$ & $(-2.851)$ & $(-5.131)$ & $(-4.622)$ & $(-4.800)$ & $(-1.715)$ & $(-7.682)$ \\
\hline \multirow[t]{2}{*}{ Float (dummy) } & -0.099 & -0.024 & -0.013 & -0.048 & -0.078 & -0.075 & -0.043 \\
\hline & $(-4.528)$ & $(-1.133)$ & $(-0.589)$ & $(-2.420)$ & $(-3.965)$ & $(-4.694)$ & $(-5.461)$ \\
\hline \multirow[t]{2}{*}{ Not semi-annual coupon (dummy) } & -0.01 & -0.023 & -0.064 & -0.06 & -0.049 & -0.077 & -0.061 \\
\hline & $(-0.442)$ & $(-1.081)$ & $(-2.998)$ & $(-3.253)$ & $(-2.758)$ & $(-4.925)$ & $(-7.868)$ \\
\hline \multirow[t]{2}{*}{ Time to Maturity in years } & -0.001 & -0.001 & -0.001 & -0.001 & 0 & -0.001 & -0.001 \\
\hline & $(-1.425)$ & $(-3.334)$ & $(-2.291)$ & $(-2.787)$ & $(-0.838)$ & $(-2.211)$ & $(-5.444)$ \\
\hline \multirow[t]{2}{*}{ Coupon } & 0.001 & 0.009 & 0.005 & 0.007 & 0.011 & 0.003 & 0.005 \\
\hline & $(0.355)$ & (3.611) & (1.967) & $(3.172)$ & (5.043) & $(1.743)$ & $(5.328)$ \\
\hline Adj-R2 & 0.261 & 0.215 & 0.224 & 0.284 & 0.313 & 0.278 & 0.251 \\
\hline $\mathrm{R} 2$ & 0.264 & 0.218 & 0.227 & 0.287 & 0.315 & 0.280 & 0.252 \\
\hline $\mathrm{F}$ & 96.292 & 81.654 & 85.432 & 124.064 & 149.807 & 142.180 & 483.509 \\
\hline P-Value & 0.000 & 0.000 & 0.000 & 0.000 & 0.000 & 0.000 & 0.000 \\
\hline Count & 4585 & 5012 & 4968 & 5265 & 5548 & 6225 & 31603 \\
\hline
\end{tabular}


Table 13: Liquidity regression on traded set using trade count as the measure of liquidity

This table presents the results of a multiple regression where trade count (expressed as a percentile) is the dependent variable. The numbers in each cell represent the regression coefficients for the independent variables in the first column with the $t$ statistic in parenthesis. The independent variables are shown in the first column under the heading Regression Variables. The credit rating is Moody's rating represented as a quintile (number 1 through 5), with Aaa being 1 and below Baa3 being 5 . These variables are identified as of first trade of year. The regression analysis is performed each year for a set of US corporate bonds that traded at least once in the State Street Corporation's custody trades database. The last column provides the results for the sample pooled across the years 1999-2004. To calculate the trade count percentile (the dependent variable), we first divide the number of trades for the given issue in the given year, by the amount outstanding as of the first trade day for that year. These normalized values are arranged in increasing order, for a given year and a percentile number is calculated. A higher trade count percentile value indicates higher liquidity.

\begin{tabular}{llllllll}
\hline Regression Variables & 1999 & 2000 & 2001 & 2002 & 2003 & 2004 & $1999-2004$ \\
\hline Constant & 0.392 & 0.294 & 0.358 & 0.254 & 0.178 & 0.24 & 0.276 \\
& $(14.799)$ & $(11.347)$ & $(13.480)$ & $(10.467)$ & $(7.836)$ & $(11.725)$ & $(26.353)$ \\
Industrial Sector (dummy) & -0.033 & -0.045 & -0.055 & -0.06 & -0.041 & -0.036 & -0.046 \\
& $(-3.105)$ & $(-4.040)$ & $(-4.874)$ & $(-5.996)$ & $(-4.369)$ & $(-3.961)$ & $(-10.985)$ \\
Financial Sector (dummy) & -0.049 & -0.039 & -0.066 & -0.07 & -0.044 & -0.046 & -0.051 \\
& $(-4.107)$ & $(-3.214)$ & $(-5.428)$ & $(-6.441)$ & $(-4.295)$ & $(-4.691)$ & $(-11.279)$ \\
Utility Sector (dummy) & -0.057 & -0.057 & -0.083 & -0.134 & -0.089 & -0.085 & -0.084 \\
& $(-4.307)$ & $(-4.164)$ & $(-6.137)$ & $(-10.943)$ & $(-7.702)$ & $(-7.588)$ & $(-16.341)$ \\
Credit Rating (Moodys) & 0.071 & 0.075 & 0.068 & 0.082 & 0.089 & 0.091 & 0.081 \\
& $(14.887)$ & $(16.077)$ & $(15.050)$ & $(20.293)$ & $(22.641)$ & $(24.482)$ & $(46.794)$ \\
Age of Bond & -0.016 & -0.014 & -0.014 & -0.015 & -0.019 & -0.021 & -0.017 \\
& $(-14.063)$ & $(-11.649)$ & $(-13.076)$ & $(-12.373)$ & $(-16.773)$ & $(-20.448)$ & $(-36.122)$ \\
Original Maturity 5 year & 0.003 & 0.015 & -0.004 & -0.002 & -0.019 & -0.01 & 0.003 \\
& $(\mathbf{0 . 2 2 3})$ & $(1.259)$ & $(-0.310)$ & $(-0.212)$ & $(-1.853)$ & $(-1.003)$ & $(0.545)$ \\
Original Maturity 7 year & -0.008 & 0.002 & 0.016 & 0.001 & 0.006 & 0.019 & 0.006 \\
& $(-0.671)$ & $(0.131)$ & $(1.203)$ & $(0.103)$ & $(0.479)$ & $(1.671)$ & $(1.286)$ \\
Original Maturity 30 year & -0.064 & -0.035 & -0.001 & 0.008 & -0.015 & 0.002 & -0.017 \\
& $(-4.797)$ & $(-2.467)$ & $(-0.046)$ & $(0.595)$ & $(-1.162)$ & $(0.162)$ & $(-3.211)$ \\
Amount Outstanding & -0.149 & -0.087 & -0.086 & 0.016 & 0.045 & 0.058 & -0.031 \\
Callable (dummy) & $(-11.534)$ & $(-6.792)$ & $(-6.525)$ & $(1.297)$ & $(3.674)$ & $(5.018)$ & $(-6.102)$ \\
& 0.065 & 0.045 & 0.057 & 0.053 & 0.037 & 0.002 & 0.042 \\
& $(7.129)$ & $(5.113)$ & $(6.612)$ & $(6.467)$ & $(4.793)$ & $(0.252)$ & $(12.619)$
\end{tabular}


Table 13: Liquidity regression on traded set using trade count as the measure of liquidity (continued)

\begin{tabular}{|c|c|c|c|c|c|c|c|}
\hline Regression Variables & 1999 & 2000 & 2001 & 2002 & 2003 & 2004 & 1999-2004 \\
\hline Putable (dummy) & $\begin{array}{l}-0.028 \\
(-1.274)\end{array}$ & $\begin{array}{l}-0.047 \\
(-2.031)\end{array}$ & $\begin{array}{l}-0.008 \\
(-0.339)\end{array}$ & $\begin{array}{l}-0.032 \\
(-1.447)\end{array}$ & $\begin{array}{l}-0.056 \\
(-2.544)\end{array}$ & $\begin{array}{l}-0.032 \\
(-1.423)\end{array}$ & $\begin{array}{l}-0.051 \\
(-5.632)\end{array}$ \\
\hline Convertible (dummy) & $\begin{array}{l}0.058 \\
(2.344)\end{array}$ & $\begin{array}{l}-0.021 \\
(-0.753)\end{array}$ & $\begin{array}{l}-0.032 \\
(-1.234)\end{array}$ & $\begin{array}{l}-0.13 \\
(-5.370)\end{array}$ & $\begin{array}{l}-0.097 \\
(-4.344)\end{array}$ & $\begin{array}{l}-0.159 \\
(-6.610)\end{array}$ & $\begin{array}{l}-0.071 \\
(-7.209)\end{array}$ \\
\hline Sinkable (dummy) & $\begin{array}{l}0.03 \\
(1.385)\end{array}$ & $\begin{array}{l}-0.033 \\
(-1.475)\end{array}$ & $\begin{array}{l}-0.091 \\
(-4.357)\end{array}$ & $\begin{array}{l}-0.08 \\
(-4.034)\end{array}$ & $\begin{array}{l}-0.078 \\
(-4.003)\end{array}$ & $\begin{array}{l}-0.012 \\
(-\mathbf{0 . 6 2 8})\end{array}$ & $\begin{array}{l}-0.046 \\
(-5.436)\end{array}$ \\
\hline Float (dummy) & $\begin{array}{l}-0.09 \\
(-4.142)\end{array}$ & $\begin{array}{l}-0.013 \\
(-0.616)\end{array}$ & $\begin{array}{l}-0.003 \\
(-0.139)\end{array}$ & $\begin{array}{l}-0.03 \\
(-1.561)\end{array}$ & $\begin{array}{l}-0.072 \\
(-3.750)\end{array}$ & $\begin{array}{l}-0.073 \\
(-4.678)\end{array}$ & $\begin{array}{l}-0.034 \\
(-4.301)\end{array}$ \\
\hline Not semi-annual coupon (dummy) & $\begin{array}{l}-0.01 \\
(-0.456)\end{array}$ & $\begin{array}{l}-0.018 \\
(-0.861)\end{array}$ & $\begin{array}{l}-0.051 \\
(-2.423)\end{array}$ & $\begin{array}{l}-0.061 \\
(-\mathbf{3 . 3 7 3})\end{array}$ & $\begin{array}{l}-0.04 \\
(-2.315)\end{array}$ & $\begin{array}{l}-0.072 \\
(-4.682)\end{array}$ & $\begin{array}{l}-0.056 \\
(-7.323)\end{array}$ \\
\hline Time to Maturity in years & $(-1.029)$ & $\begin{array}{l}-0.001 \\
(-2.885)\end{array}$ & $\begin{array}{l}-0.001 \\
(-1.837)\end{array}$ & $\begin{array}{l}-0.001 \\
(-2.322)\end{array}$ & $(-0.244)$ & $\begin{array}{l}-0.001 \\
(-1.775)\end{array}$ & $\begin{array}{l}-0.001 \\
(-4.332)\end{array}$ \\
\hline Coupon & $\begin{array}{l}0.002 \\
(\mathbf{0 . 7 6 4 )}\end{array}$ & $\begin{array}{l}0.01 \\
(4.067)\end{array}$ & $\begin{array}{l}0.008 \\
\mathbf{( 3 . 0 3 8 )}\end{array}$ & $\begin{array}{l}0.009 \\
\mathbf{( 3 . 9 8 3 )}\end{array}$ & $\begin{array}{l}0.013 \\
(6.144)\end{array}$ & $\begin{array}{l}0.007 \\
\mathbf{( 3 . 3 5 2 )}\end{array}$ & $\begin{array}{l}0.007 \\
(7.530)\end{array}$ \\
\hline Adj-R2 & 0.270 & 0.224 & 0.235 & 0.305 & 0.333 & 0.305 & 0.267 \\
\hline $\mathrm{R} 2$ & 0.273 & 0.227 & 0.237 & 0.307 & 0.335 & 0.307 & 0.268 \\
\hline $\mathrm{F}$ & 100.826 & 86.221 & 90.560 & 136.670 & 163.964 & 161.942 & 525.295 \\
\hline P-Value & 0.000 & 0.000 & 0.000 & 0.000 & 0.000 & 0.000 & 0.000 \\
\hline Count & 4585 & 5012 & 4968 & 5265 & 5548 & 6225 & 31603 \\
\hline
\end{tabular}


Table 14: Liquidity regression on traded set using traded market value as the measure of liquidity

This table presents the results of a multiple regression where trade market value (expressed as a percentile) is the dependent variable. The numbers in each cell represent the regression coefficients for the independent variables in the first column with the $t$ statistic in parenthesis. The independent variables are shown in the first column under the heading Regression Variables. The credit rating is Moody's rating represented as a quintile (number 1 through 5), with Aaa being 1 and below Baa3 being 5. These variables are identified as of first trade of year. The regression analysis is performed each year for a set of US corporate bonds that traded at least once from the State Street Corporation's custody trades database. The last column provides the results for the sample pooled across the years 1999-2004. To calculate the trade market value percentile (the dependent variable), we first divide the total market value of trades for the given issue in the given year, by the amount outstanding as of the first trade day for that year. These normalized values are arranged in increasing order, for a given year and a percentile number is calculated. A higher trade market value percentile value indicates higher liquidity.

\begin{tabular}{|c|c|c|c|c|c|c|c|}
\hline Regression Variables & 1999 & 2000 & 2001 & 2002 & 2003 & 2004 & 1999-2004 \\
\hline Constant & $\begin{array}{l}0.505 \\
(16.708)\end{array}$ & $\begin{array}{l}0.418 \\
(14.634)\end{array}$ & $\begin{array}{l}0.504 \\
(17.074)\end{array}$ & $\begin{array}{l}0.421 \\
(15.503)\end{array}$ & $\begin{array}{l}0.271 \\
(10.858)\end{array}$ & $\begin{array}{l}0.324 \\
(14.557)\end{array}$ & $\begin{array}{l}0.395 \\
(34.030)\end{array}$ \\
\hline Industrial Sector (dummy) & $\begin{array}{l}-0.029 \\
(-2.385)\end{array}$ & $\begin{array}{l}-0.031 \\
(-2.559)\end{array}$ & $\begin{array}{l}-0.026 \\
(-2.076)\end{array}$ & $\begin{array}{l}-0.048 \\
(-4.328)\end{array}$ & $\begin{array}{l}-0.051 \\
(-4.889)\end{array}$ & $\begin{array}{l}-0.041 \\
(-4.097)\end{array}$ & $\begin{array}{l}-0.04 \\
(-8.512)\end{array}$ \\
\hline Financial Sector (dummy) & $\begin{array}{l}-0.037 \\
(-2.761)\end{array}$ & $\begin{array}{l}-0.017 \\
(-1.286)\end{array}$ & $\begin{array}{l}-0.034 \\
(-2.549)\end{array}$ & $\begin{array}{l}-0.069 \\
(-5.679)\end{array}$ & $\begin{array}{l}-0.046 \\
(-4.071)\end{array}$ & $\begin{array}{l}-0.052 \\
(-4.903)\end{array}$ & $\begin{array}{l}-0.042 \\
(-8.389)\end{array}$ \\
\hline Utility Sector (dummy) & $\begin{array}{l}-0.016 \\
(-1.047)\end{array}$ & $\begin{array}{l}-0.015 \\
(-1.023)\end{array}$ & $\begin{array}{l}-0.045 \\
(-3.030)\end{array}$ & $\begin{array}{l}-0.119 \\
(-8.706)\end{array}$ & $\begin{array}{l}-0.095 \\
(-7.499)\end{array}$ & $\begin{array}{l}-0.096 \\
(-7.925)\end{array}$ & $\begin{array}{l}-0.067 \\
(-11.843)\end{array}$ \\
\hline Credit Rating (Moodys) & $\begin{array}{l}0.026 \\
(4.788)\end{array}$ & $\begin{array}{l}0.035 \\
(6.838)\end{array}$ & $\begin{array}{l}0.028 \\
(\mathbf{5 . 6 5 8})\end{array}$ & $\begin{array}{l}0.046 \\
(10.208)\end{array}$ & $\begin{array}{l}0.066 \\
(15.387)\end{array}$ & $\begin{array}{l}0.06 \\
(14.718)\end{array}$ & $\begin{array}{l}0.046 \\
(24.118)\end{array}$ \\
\hline Age of Bond & $\begin{array}{l}-0.019 \\
(-14.341)\end{array}$ & $\begin{array}{l}-0.017 \\
(-12.839)\end{array}$ & $\begin{array}{l}-0.013 \\
(-11.058)\end{array}$ & $\begin{array}{l}-0.014 \\
(-10.465)\end{array}$ & $\begin{array}{l}-0.018 \\
(-14.692)\end{array}$ & $\begin{array}{l}-0.021 \\
(-18.179)\end{array}$ & $\begin{array}{l}-0.017 \\
(-32.748)\end{array}$ \\
\hline Original Maturity 5 year & $\begin{array}{l}-0.014 \\
(-0.919)\end{array}$ & $\begin{array}{l}0.015 \\
(1.099)\end{array}$ & $\begin{array}{l}-0.003 \\
(-0.230)\end{array}$ & $\begin{array}{l}-0.01 \\
(-0.813)\end{array}$ & $\begin{array}{l}-0.026 \\
(-2.248)\end{array}$ & $\begin{array}{l}-0.006 \\
(-0.553)\end{array}$ & $\begin{array}{l}-0.002 \\
(-0.426)\end{array}$ \\
\hline Original Maturity 7 year & $\begin{array}{l}-0.024 \\
(-1.647)\end{array}$ & $\begin{array}{l}-0.013 \\
(-0.920)\end{array}$ & $\begin{array}{l}-0.014 \\
(-0.976)\end{array}$ & $\begin{array}{l}-0.016 \\
(-1.224)\end{array}$ & $\begin{array}{l}-0.003 \\
(-0.233)\end{array}$ & $\begin{array}{l}0.004 \\
(\mathbf{0 . 2 9 8 )}\end{array}$ & $\begin{array}{l}-0.008 \\
(-1.448)\end{array}$ \\
\hline Original Maturity 30 year & $\begin{array}{l}-0.009 \\
(-0.606)\end{array}$ & $\begin{array}{l}0.02 \\
(\mathbf{1 . 2 9 1 )}\end{array}$ & $\begin{array}{l}0.034 \\
(2.146)\end{array}$ & $\begin{array}{l}0.026 \\
(1.755)\end{array}$ & $\begin{array}{l}0.009 \\
(0.690)\end{array}$ & $\begin{array}{l}0.033 \\
(2.413)\end{array}$ & $\begin{array}{l}0.019 \\
(\mathbf{3 . 1 9 1})\end{array}$ \\
\hline Amount Outstanding & $\begin{array}{l}-0.007 \\
(-0.485)\end{array}$ & $\begin{array}{l}0.061 \\
(4.311)\end{array}$ & $\begin{array}{l}0.061 \\
(4.155)\end{array}$ & $\begin{array}{l}0.134 \\
\mathbf{( 9 . 4 0 6 )}\end{array}$ & $\begin{array}{l}0.15 \\
(11.145)\end{array}$ & $\begin{array}{l}0.175 \\
(13.785)\end{array}$ & $\begin{array}{l}0.095 \\
(16.802)\end{array}$ \\
\hline Callable (dummy) & $\begin{array}{l}0.012 \\
(1.204)\end{array}$ & $\begin{array}{l}-0.022 \\
(-\mathbf{2 . 3 1 3})\end{array}$ & $(-0.013)$ & $\begin{array}{l}0.012 \\
(1.282)\end{array}$ & $\begin{array}{l}0.015 \\
(1.832)\end{array}$ & $\begin{array}{l}-0.024 \\
(-3.092)\end{array}$ & $\begin{array}{l}-0.001 \\
(-0.150)\end{array}$ \\
\hline Putable (dummy) & -0.058 & -0.008 & 0 & -0.06 & -0.072 & -0.038 & -0.049 \\
\hline
\end{tabular}


Table 14: Liquidity regression on traded set using traded market value as the measure of liquidity (continued)

\begin{tabular}{|c|c|c|c|c|c|c|c|}
\hline Regression Variables & 1999 & 2000 & 2001 & 2002 & 2003 & 2004 & $1999-2004$ \\
\hline & $(-2.314)$ & $(-0.330)$ & $(0.001)$ & $(-2.388)$ & $(-3.010)$ & $(-1.545)$ & $(-4.863)$ \\
\hline \multirow[t]{2}{*}{ Convertible (dummy) } & -0.12 & -0.178 & -0.199 & -0.262 & -0.235 & -0.233 & -0.213 \\
\hline & $(-4.266)$ & $(-5.793)$ & $(-6.872)$ & $(-9.631)$ & $(-9.591)$ & $(-8.897)$ & $(-19.500)$ \\
\hline \multirow[t]{2}{*}{ Sinkable (dummy) } & 0.016 & -0.04 & -0.103 & -0.109 & -0.102 & -0.044 & -0.07 \\
\hline & $(0.645)$ & $(-1.592)$ & $(-4.443)$ & $(-4.959)$ & $(-4.745)$ & $(-2.038)$ & $(-7.512)$ \\
\hline \multirow[t]{2}{*}{ Float (dummy) } & 0.016 & 0.105 & 0.122 & 0.095 & 0.032 & 0.023 & 0.074 \\
\hline & $(0.652)$ & $(4.439)$ & $(5.158)$ & $(4.361)$ & $(1.526)$ & $(1.335)$ & $(8.510)$ \\
\hline \multirow[t]{2}{*}{ Not semi-annual coupon (dummy) } & 0.025 & -0.018 & -0.051 & -0.074 & -0.008 & -0.003 & -0.027 \\
\hline & $(0.989)$ & $(-0.764)$ & $(-2.170)$ & $(-3.628)$ & $(-0.396)$ & $(-0.204)$ & $(-3.224)$ \\
\hline \multirow[t]{2}{*}{ Time to Maturity in years } & 0 & -0.002 & 0 & 0 & 0.001 & -0.001 & -0.001 \\
\hline & $(0.188)$ & $(-3.473)$ & $(-1.032)$ & $(-0.490)$ & $(1.394)$ & $(-2.739)$ & $(-2.661)$ \\
\hline \multirow[t]{2}{*}{ Coupon } & -0.001 & 0.003 & -0.007 & -0.005 & 0.004 & 0.003 & -0.002 \\
\hline & $(-0.464)$ & $(0.948)$ & $(-2.452)$ & $(-1.912)$ & $(1.745)$ & $(1.403)$ & $(-1.572)$ \\
\hline Adj-R2 & 0.079 & 0.081 & 0.076 & 0.146 & 0.211 & 0.191 & 0.121 \\
\hline $\mathrm{R} 2$ & 0.082 & 0.084 & 0.079 & 0.149 & 0.213 & 0.194 & 0.121 \\
\hline $\mathrm{F}$ & 24.063 & 26.916 & 24.956 & 53.943 & 88.060 & 87.659 & 197.939 \\
\hline P-Value & 0.000 & 0.000 & 0.000 & 0.000 & 0.000 & 0.000 & 0.000 \\
\hline Count & 4585 & 5012 & 4968 & 5265 & 5548 & 6225 & 31603 \\
\hline
\end{tabular}


Table 15: Liquidity regression on the full US corporate holding data set using using latent liquidity as the measure of liquidity

This table presents the results of a multiple regression where latent liquidity (expressed as a percentile) is the dependent variable. The numbers in each cell represent the regression coefficients for the independent variables in the first column with the $t$-statistic in parenthesis. The independent variables are shown in the first column under the heading Regression Variables. The credit rating is Moody's rating represented as a quintile (number 1 through 5), with Aaa being 1 and below Baa3 being 5 . These variables are identified as of the first trade of the year. The regression analysis is performed each year for the full set of US corporate bonds in State Street Corporation's custody holdings database, including bonds that did not trade in the calendar year. The last column provides the results for the sample pooled across the years 19992004. To calculate the latent liquidity percentile (the dependent variable), latent liquidity values are identified as of first trade date of year. These values are arranged in increasing order, for a given year and a percentile number is calculated. A higher latent liquidity percentile value indicates higher liquidity.

\begin{tabular}{llllllll}
\hline Regression Variables & 1999 & 2000 & 2001 & 2002 & $\mathbf{2 0 0 3}$ & $\mathbf{2 0 0 4}$ & $1999-2004$ \\
\hline Constant & 0.276 & 0.281 & 0.257 & 0.245 & 0.243 & 0.151 & 0.23084109 \\
& $(13.162)$ & $(13.249)$ & $(11.756)$ & $(11.797)$ & $(11.455)$ & $(7.820)$ & 25.832248 \\
Industrial Sector (dummy) & -0.059 & -0.028 & -0.044 & -0.042 & -0.051 & -0.026 & -0.04171465 \\
& $(-6.531)$ & $(-3.063)$ & $(-4.746)$ & $(-4.779)$ & $(-5.624)$ & $(-2.959)$ & -11.22302 \\
Financial Sector (dummy) & 0.02 & 0.028 & 0.003 & 0.019 & 0.007 & -0.001 & 0.013838924 \\
& $(2.138)$ & $(2.810)$ & $(0.282)$ & $(2.013)$ & $(0.700)$ & $(-0.072)$ & 3.4872585 \\
Utility Sector (dummy) & -0.074 & -0.04 & -0.035 & -0.04 & -0.041 & -0.014 & -0.03844475 \\
& $(-6.945)$ & $(-3.677)$ & $(-3.240)$ & $(-3.889)$ & $(-3.871)$ & $(-1.325)$ & -8.8542606 \\
Credit Rating (Moodys) & 0.038 & 0.02 & 0.016 & 0.022 & 0.027 & 0.067 & 0.033548958 \\
& $(10.376)$ & $(5.563)$ & $(4.488)$ & $(6.488)$ & $(8.020)$ & $(20.332)$ & 23.405323 \\
Age of Bond & -0.015 & -0.014 & -0.011 & -0.012 & -0.014 & -0.012 & -0.01306762 \\
& $(-19.576)$ & $(-17.875)$ & $(-14.305)$ & $(-15.010)$ & $(-14.427)$ & $(-14.523)$ & -39.482223 \\
Original Maturity 5 year & 0.1 & 0.11 & 0.135 & 0.076 & 0.089 & 0.084 & 0.098703342 \\
& $(9.545)$ & $(10.319)$ & $(11.617)$ & $(6.995)$ & $(8.353)$ & $(8.278)$ & $\mathbf{2 2 . 5 4 9 9 4 2}$ \\
Original Maturity 7 year & 0.083 & 0.074 & 0.086 & 0.034 & 0.044 & 0.063 & 0.064407096 \\
& $(8.290)$ & $(6.863)$ & $(7.768)$ & $(3.173)$ & $(3.849)$ & $(5.541)$ & 14.446537 \\
Original Maturity 30 year & -0.107 & -0.072 & -0.071 & -0.043 & -0.041 & -0.021 & -0.05714518 \\
Amount Outstanding & $(-10.300)$ & $(-6.921)$ & $(-6.863)$ & $(-4.232)$ & $(-3.982)$ & $(-2.013)$ & -13.51844 \\
& 0.059 & 0.125 & 0.144 & 0.209 & 0.166 & 0.128 & 0.13477524 \\
& $(5.700)$ & $(12.019)$ & $(13.527)$ & $(19.213)$ & $(14.467)$ & $(11.665)$ & $\mathbf{3 0 . 8 0 3 7 0 1}$
\end{tabular}


Table 15: Liquidity regression on the full US corporate holding data set using using latent liquidity as the measure of liquidity (continued)




Table 16: Liquidity panel regression on the non-traded set using latent liquidity as a measure of liquidity

This table presents the results of a multiple regression where latent liquidity (expressed as a percentile) is the dependent variable. The numbers in each cell represent the regression coefficients for the independent variables in the first column with the $t$-statistic in parenthesis. The independent variables are shown in the first column under the heading Regression Variables . The credit rating is Moody's rating represented as a quintile (number 1 through 5), with Aaa being 1 and below Baa3 being 5 . These variables are identified as of the first trade of the year. The regression analyses is performed for the non-traded set (i.e. the ones that did not even trade once a year) of US corporate bonds in State Street Corporation's custody holdings database. The table provides the results for the sample pooled across theyears 1999-2004. To calculate the latent liquidity percentile (the dependent variable), latent liquidity values are identified as of first trade date of year. These values are arranged in increasing order, for a given year and a percentile number is calculated. A higher latent liquidity percentile value indicates higher liquidity.

\begin{tabular}{ll}
\hline Regression Variables & $\begin{array}{l}\text { Latent } \\
\text { Liquidity }\end{array}$ \\
\hline Constant & 0.18306798 \\
& $(\mathbf{1 2 . 3 7 8 9 4 8 )}$ \\
Industrial Sector (dummy) & -0.040301468 \\
& $(-6.1629971)$ \\
Financial Sector (dummy) & 0.027697603 \\
& $(4.0245696)$ \\
Utility Sector (dummy) & -0.031238385 \\
& $(-4.3067682)$ \\
Credit Rating (Moodys) rank & 0.035903312 \\
Age of Bond in years & $(15.832037)$ \\
Original Maturity 5 year (dummy) & -0.005382361 \\
& $(-11.537633)$ \\
Original Maturity 7 year (dummy) & 0.10851874 \\
& $(\mathbf{1 2 . 6 1 7 5 9 3 )}$ \\
& 0.088299743 \\
& $(11.206349)$
\end{tabular}


Table 16: Liquidity panel regression on the non-traded set using latent liquidity as a measure of liquidity (continued)

\begin{tabular}{ll}
\hline Regression Variables & $\begin{array}{l}\text { Latent } \\
\text { Liquidity }\end{array}$ \\
\hline Original Maturity 30 year (dummy) & -0.05988744 \\
& $\mathbf{( - 9 . 5 7 9 2 7 0 8 )}$ \\
Amount Outstanding (\$Billions) & 0.045450888 \\
& $(6.4001899)$ \\
Callable (dummy) & 0.038663653 \\
& $(8.4199134)$ \\
Putable (dummy) & 0.12577787 \\
& $(14.04388)$ \\
Convertible (dummy) & 0.16017459 \\
Sinkable (dummy) & $(13.314638)$ \\
& -0.03561858 \\
Float (dummy) & $\mathbf{( - 4 . 5 3 7 5 4 9 2 )}$ \\
& -0.029882273 \\
Not semi-annual coupon (dummy) & $(\mathbf{- 2 . 5 9 2 0 6 7 2 )}$ \\
Time to Maturity in years & 0.098980213 \\
& $(8.7561688)$ \\
Coupon & 0.001250828 \\
& $(5.6911709)$ \\
Adj-R2 & 0.021066615 \\
R2 & $(15.540587)$ \\
F & \\
Count & 0.12451941 \\
& 0.12554576 \\
& 122.322 \\
& 0 \\
& 18767 \\
\hline
\end{tabular}

